\title{
4. Untangling Elite Networks and Decentralization in the Middle East and North Africa: Neopatrimonialism Revisited
}

Miriam Bohn and Erik Vollmann

Politics in the Middle East and North Africa (MENA) is an amalgamation of formal-legal institutions and informal rules built on a highly personalist structure of power relations known as neopatrimonialism. Though the periphery is central to this type of personalist governance, the subnational dimension of neopatrimonialism was vastly neglected in past research. Since both our understanding of autocracy and neopatrimonialism build upon the notion of power-centralization in the hands of the ruler and the central regime, the state-centeredness of most research on the MENA region is reasonable. In light of the revival of decentralization efforts and discourses following the Arab uprisings of 2010/11, however, we argue that a thorough analysis of the relationship between local governance reforms and neopatrimonialism is key to advancing our understanding of governance and policy formulation in the MENA region. Though mostly not considered to be part of high politics, decentralization reforms have a significant impact on patron-client relations between the central level and the subnational territories of the body politic (Cammack et al. 2007; Demmelhuber et al. 2020). A systematic analysis of central and subnational elite dynamics is thus essential to broaden our understanding of decentralization under neopatrimonialism. Patron-client networks are asymmetric power relations with a clear dominance of the ruler as "prime patron", yet he is also dependent on the compliance and the successful management of his clientelist networks. We argue that the country-specific interplay of central and subnational elite networks has an impact on the de jure formulation and the de facto outcome of decentralization processes, and vice versa.

The purpose of this contribution is to examine which role neopatrimonialism and elite dynamics play in shaping the process and outcome of decentralization, with a focus on the post-2011 developments in four MENA countries (Morocco, Jordan, Tunisia, and Egypt). A core element of neopatrimonialism is a well-balanced interplay of both formal and informal institutions. Neither the idealistic absence of the informal (legalisticbureaucratic) rule, nor the complete dominance of informal politics (patri- 
monialism) alone can explain politics in the political system (Erdmann and Engel 2007). We focus on the de facto process and outcome after the implementation rather than the de jure formulation of the reforms. Based on fieldwork interviews and observations as well as the literature on neopatrimonialism, decentralization and informal institutions, our analysis explores three main questions:

- How do national and subnational elites use both formal and informal institutions in their attempt to gain and maintain influence, resources, and power?

- Decentralization processes have the potential to reconfigure elite networks from the center down to the local level and can thus be both threat and opportunity for different strata of elites. Can we see significant changes in elite constellations between the center and the subnational levels?

- How does elite behavior explain the deviations between the legal institutional design of decentralization and its de facto outcome?

The inclusion of regional disparities is crucial to understand the logic of subnational governance in the MENA. The regimes have been using neopatrimonial networks to handle the periphery for decades, but the dynamics of 2011 revealed the limits of this supposed security network, as most of the protests originated from the socio-politically neglected periphery. Over time, most political and economic power in MENA countries was concentrated in the center and a few well-connected regions. The result was a major gap between urban and rural regions concerning public services, development, and political influence. Consequently, the implementation of decentralization reforms in MENA countries may on the one hand contribute to appease peripheral populations by granting them more venues of participation, authority over subnational state affairs, and by boosting their economic development. In addition, reforms may increase central control over the periphery depending on the legislative design. On the other hand, not only does decentralization challenge existing clientelist structures that have been used to stabilize the regime for decades (Clark 2018), it also means giving away power to a population that has proven its willingness to stand up against the regime if necessary. Therefore, our empirical analysis adds center-periphery disparities to the examination of our 
three research questions as these disparities are main drivers of recent decentralization processes (Vollmann 2020). ${ }^{1}$

\section{Decentralization, neopatrimonialism and elites in the MENA}

\section{Decentralization in the MENA}

Decentralization is the transfer of competences from the central government level down to the subnational levels of government, for example to the regional and the local political administration (Demmelhuber et al. 2020). Despite a historical tradition of strong elites in the periphery, MENA regimes are nowadays infamous for their centralized state order. Decentralized power arrangements among various traditional leaders (e.g., tribal or religious) characterized the MENA region long before Western states imposed their colonial rule upon the territories. When colonial powers established a centralized, bureaucratic state administration, they engaged with the traditional elites in form of decentralized power sharing to make them comply with the new state. After gaining independence, the region's new rulers built upon the colonial state administration and continued to centralize their power. They assumed a variety of strategies that simultaneously upheld and marginalized the position of traditional elites. For instance, the new power holders used strategic co-optation of local notables (e.g. Morocco) and marginalized their power via formal-legal measures such as the merger of municipalities (e.g. Jordan) (Charrad 2011; Harb and Atallah 2015; Vollmann 2020; Shalaby et al. 2020; Demmelhuber et al. 2020; Bouabid and Iraki 2015).

Though Western donors generally advocate decentralization in MENA countries, even World Bank researchers no longer deny that the topic is much more complex than it being a technical measure leading to good governance. Politicians and bureaucrats fight over decentralization for the same reasons they fight over the design of state institutions: Their power

1 Our analysis draws on original fieldwork in Morocco (April 2018 - May 2018 and October 2018 - December 2018), Jordan (April 2018 - May 2018, October 2018 November 2018 and January 2020 - February 2020), and Tunisia (October 2019 November 2019 and January 2020 - February 2020) where we conducted semistructured interviews $(n=162)$ with politicians and state employees, civil society actors, researchers, journalists, and foreign observer organizations on the central, regional, and local government levels. For an extensive fieldwork description and our rationale behind the case selection see chapter 3 . 
and authority are at stake (Eaton, Kaiser, and Smoke 2010, 1). A meaningful delegation of tasks and power away from the center should be an anathema to the interest of centralized authoritarian states. Are decentralization reforms thus just "window dressing" without any meaningful impact on governance in the MENA? Building on the literature on neopatrimonialism and informal politics, we argue that local governance reform and the relationship between national and subnational elites are pivotal to understanding politics even in the highly centralized MENA region.

\section{Neopatrimonialism and decentralization}

Despite different pathways for the organization of power and of approaches towards the periphery, the personalist character of politics is indisputable in all our four cases. ${ }^{2}$ Drawing on V-Dem data, neopatrimonialism has clearly been present in the four countries for a long period of time (see Figure 1). The rulers built their power on extensive patron-client networks that laid the foundation for neopatrimonial political systems. Consequently, a systematic amalgamation of legal-formal institutions and informal elite interactions characterizes the political process in Jordan, Egypt, Tunisia, and Morocco (Demmelhuber et al. 2020).

Neopatrimonialism is a type of rule that combines features of two Weberian ideal types: bureaucratic-legalistic rule and patrimonialism (Eisenstadt 1973; von Soest 2010; Erdmann and Engel 2007). Legal-rational institutions exist and visibly structure the state organization. We see the formal separation of the public and private sphere and officials holding positions in bureaucratic organizations. However, authority is heavily personalized and state elites exercise their legally-defined powers "as a form not of public service but of private property" (Clapham 1985, 48). Moreover, the traditional linkages of authority might persist, though in a less pronounced

2 While Tunisia's transformation process resulted in an extremely positive rating by V-Dem, neopatrimonial networks especially between economic elites and ministerial elites are still intact (see the section on Tunisia in this chapter). Also, the perception of public corruption is high. A majority of Tunisians was convinced that corruption had risen during the last year both in 2016 (64\%) and 2019 (67\%). Tunisians experience it as a national and subnational problem. $31 \%$ of the population believes the government to be corrupt, as do $27 \%$ regarding local councilors (2019) (Transparency International 2020a; b). We thus argue that the strong neopatrimonial character, which characterized Tunisian politics over decades, has not been fully eradicated. 
version of patrimonialism, by taking on a more transactional character (Sigman and Lindberg 2017; Erdmann and Engel 2007).

Figure 1: Neopatrimonialism in the MENA region

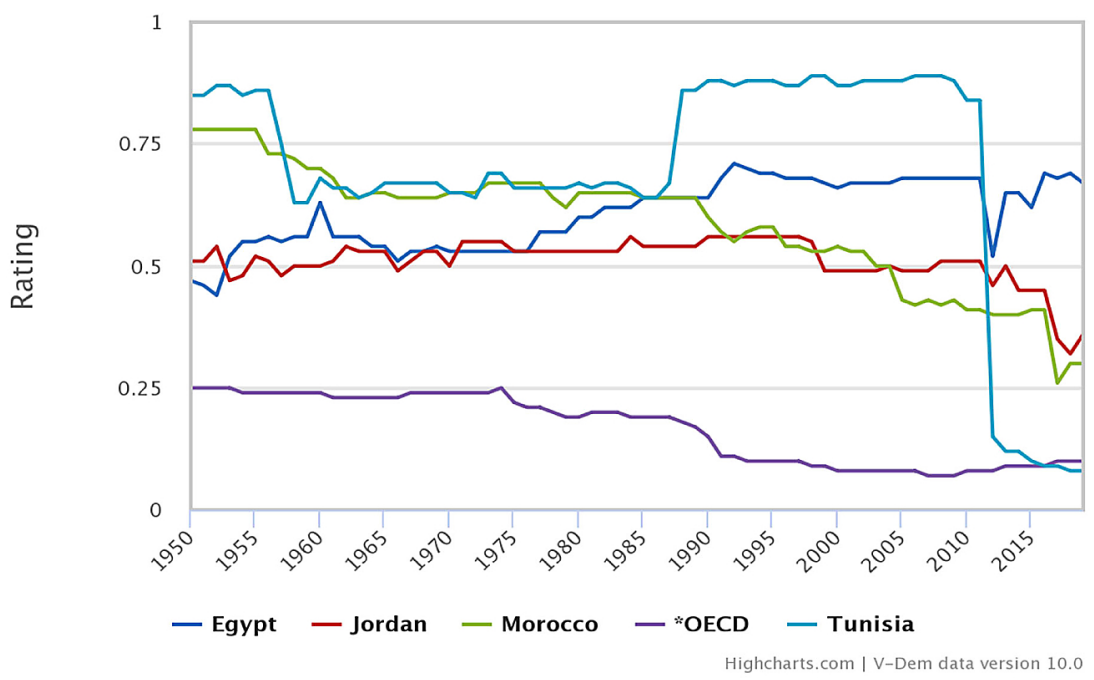

V-Dem (2020), data ranges between 0 (low neopatrimonialism) and 1 (high neopatrimonialism, composite index of indicators for the three dimensions clientelism, presidentialism, regime corruption.

Empirical approaches propose three features of neopatrimonialism: clientelism, i.e. the targeted exchange of goods and services for political support, presidentialism, which we translate into its core meaning of systematic power concentration in the hands of the ruling regime, and the elites' use of public office and resources for private or political benefit (Sigman and Lindberg 2017, 5-6; Bratton and van de Walle 1997). The last dimension includes the common occurrence of corruption as an informal institution (Teorell 2007; Helmke and Levitsky 2004). Current measurements of neopatrimonialism such as the Varieties of Democracy Index of Neopatrimonialism (see Figure 1) even use (regime) corruption as a proxy indicator for this third feature. The relatively high perception of local government corruption in our four cases also underlines the value of neopatrimonialism for the analysis of subnational government reforms. In Morocco, 38\% of the populace in 2019 perceived local governments as corrupt. Central government officials were rated as equally corrupt (2019: 37\%). We see almost the same level of corruption perception in the case of Tunisia, where 
$27 \%$ of the population view subnational councilors as corrupt $(31 \%$ for government officials). Jordanians also experience high levels of local government corruption with $28 \%$ in 2019 , but the central government is believed to be more corrupt (by 36\% of the population in 2019). Subnational perception of corruption is also very high in Egypt, with 36\% in 2016, more so than the central state officials (2016: 27\%). ${ }^{3}$ In this setting, governance is "the formation and stewardship of the formal and informal rules that regulate the public realm" (Hyden, Court, and Mease 2004). We agree with Sigman and Lindberg (2017) in their evaluation that neopatrimonialism is not a form of "African exceptionalism" but a common trait of most developing countries. ${ }^{4}$ Since power concentration that "resists delegating all but the most trivial decision-making tasks" (Bratton and van de Walle $1997,63)$ is a defining feature of neopatrimonialism, decentralization should stand in normative opposition to it. However, the personalist character of politics in neopatrimonial rule implies cooperation with elites on the ground to formulate and implement state politics. Dealing with subnational politics is therefore a core challenge of neopatrimonial state organization. On the one hand, the cooperation with local elites is necessary to govern the periphery, but on the other hand (subnational) elite power can also be a threat to the regime. An authoritarian regime's management of subnational elite structures is thus a necessary perspective to better understand the logic and functioning of neopatrimonial rule. For instance, elite rotation is a commonly applied strategy of neopatrimonial rulers to keep elites from gaining too much power within one locality (von Soest 2010). Therefore, we argue that analyzing the interplay of formal and informal institutions and systematically integrating the elite perspective is necessary to understand local governance reforms under neopatrimonialism.

\section{Elites and decentralization ${ }^{5}$}

The ruler and the regime elites are the dominant players in the network of patron-client relations. Thus, they decide on the rules for other elites' ad-

3 Data based on Transparency International 2020a; b.

4 Informal institutions are, to a degree, present in all world regions and can sometimes improve political processes and outcomes also in democratic contexts. We would also like to state that personal relations of subnational office holders and the importance of local notables are as well to be found in Western local politics. They are not per se anathema to democracy.

5 To gain a deeper understanding of our definition of elites, see chapter 3. 
vancement, rotation, or if need be punishment, by withholding rewards, privileges, and access to state resources. Elite-regime-relations might be asymmetric, but they are reciprocal. The regime relies on the support of well-connected elites and their clients for the formulation and implementation of politics, and builds on their resources and capabilities to form a basis of support for the regime.

Accordingly, the cooptation and management of elites are vital strategies of both authoritarian and neopatrimonial regimes (Gerschewski 2013; Heydemann 2007; Vollmann et al. 2020; Hinnebusch 2012; Aalen and Murias 2018). Since central patron-client networks usually reach to the local level, decentralization challenges both the structure and the rules of existing patron-client-relationships as well as the formal institutional landscape they are embedded in. MENA regimes tend to limit reform processes to purely administrative decentralization. They delegate responsibilities to state agents and subnational branches of central ministries, thereby circumventing the potential regime-threats of political or fiscal decentralization. Nevertheless, reform processes offer incentives for different strata of elites to engage with state institutions and the political regime, for instance through the creation of new jobs. New ways of participation offer the possibility to gain positions of prestige and access to state resources that in turn can be redistributed within the own personal network. Participation may even provide a chance to influence policies (Lust 2009). Decentralization can thus help to bind strong subnational elites, including oppositional actors, to the regime. However, the bottom-up reaction largely depends on the actions and attitudes of influential subnational elites towards the regime, which brings back in the regional question. Some regions are highly loyal to the central regime, other locations may be centers of oppositional activism or anti-regime forces. In the latter case, decentralization offers oppositional actors a new platform to gain voice on the subnational levels of governance and to expand their own clientelist networks. Therefore, regime strategies such as the systematic fragmentation and disorganization of party systems, as well as the repression of opposition also influence the outcome of decentralization processes. Additionally, the prevalence of informal practices such as election fraud and vote buying have a profound influence on the distribution and intentions of elites across subnational institutions. Elected members' focus on service provision in the sense of competitive clientelism (Lust 2009) strongly affects the outcome and performance of decentralization (e.g. transparency and economic development) - in many cases to the disadvantage of the broad public or poor and less influential communities. Closely related is elite capture, the possibility of elites to influence development processes in accordance with 
their personal interests and priorities. With this practice, elites retain access to resources they usually would not have (Rajasekhar et al. 2018, 22). Not only central elites can benefit from elite capture via decentralization. As Johnson et al. argue, half-hearted decentralization efforts can enable local elites to capture major shares of public resources originally allocated to the poorer part of populations (Johnson et al. 2003). Elite capture thus has a significant impact on the outcome of decentralization: It may disproportionately benefit certain individuals or groups over others. The most likely beneficiaries are strong, pro-regime elite networks rather than poor communities or regions with oppositional background. Overwhelmingly, these practices help ensure pro-regime majorities within subnational institutions instead of ensuring a heterogeneous mix that represents the community. Controlled spaces for political competition can appease and contain both the opposition and other elites without seriously endangering the status quo. To prevent strong subnational elites from gaining high degrees of influence within a community or a region, authoritarian regimes apply strategies such as elite rotation amongst appointed members of central and subnational institutions. Hence, decentralization reforms may offer additional incentives for political participation and contestation. At the same time, the newly established competition may also be part of the regime's strategy to balance power relations between elites on all levels of government, as new struggles for influence and resource distribution between different institutions emerge (see also Vollmann et al. 2020).

\section{Elites and decentralization in Morocco}

\section{Center-periphery relations: Reformism in the king's name}

The kingdom of Morocco is a unitary state with a centralized power structure surrounding the monarchy and its makhzen, i.e. the palace and its clients consisting of - amongst others - the king's advisors, economic elites, high-level bureaucrats, the security apparatus and loyal traditional elites (Hissouf 2016). The makhzen is the country's core elite network, which originates from the pre-colonial sultanate. It was originally based on religious and tribal symbols and rituals of authority, and has "formalized" and amalgamated those traditional modes of rule into the bureaucratic state apparatus of modern Morocco (for a rich historical introduction see Daadaoui 2011). Core administrative elites still largely come from makhzen families that have served the sultanate since the $15^{\text {th }}$ century. The monarchy is the largest economic player in Morocco and has used liberalization 
and privatization policies of the 1990s and 2000s to strengthen its ties with the kingdom's economic elite. Business power was traditionally and is still concentrated in the hands of only few families (Walter 2017; Lagarde, Bencheikh, and Khrouz 2011; Akdim 2013). 6 The current king Mohammed VI. advocated a strong shift away from his father's style of rule and introduced a myriad of modernization and democratization reforms that earned him his reputation as a reformer. Despite the high praise his reforms received from the international community after the Arab uprisings, Moroccan politics have shifted back to a strategy of modernization without democratization wherein the "flaws" of democratic actors are offset by "getting things done" interventions of the monarchy with (re-)increased repression (e.g. against the freedom of the press). Accordingly, Morocco is still considered a hardline autocracy (BTI 2020) despite international applause and the king's sterling international reputation as a reformer and moderating and stable anchor in the region. The king's latest diplomatic success led the US government to officially recognize Morocco's rule over the disputed Western Sahara area in exchange for the normalization of the kingdom's diplomatic ties with Israel. The Western Sahara conflict has dominated Morocco's external policies for decades. The regionalization approach to decentralization is deeply interwoven with the regime's attempts to gather international support for its claims over the Western Sahara by granting increased autonomy to the area (Collado and García 2015; White 2015). ${ }^{7}$ While the new Moroccan constitution of 2011 formally reinforced the power of democratic actors (e.g., the king now needs to choose the prime minister from the strongest party in parliament), the palace's power remains largely unrestricted. Policy projects are still mostly dependent on the king's approval or based on initiatives not from the government, but from the king's own cabinet. Though Moroccan parties are relatively strong in comparison to other MENA contexts and

6 The economic elites are often labeled as "Fassi" for those former merchant families originated from Fez, although they have since largely relocated to Casablanca. Economic and political power intertwine as the Fassi are often coopted by the palace into high-level state positions or compete for an MP status. Fassi are not restricted to - but very much include - the el Fassi family. As the patrons of the Istiqlal party with Abbas el Fassi as prime minister (2007-2011) the el Fassi illustrate that structure (Bencheikh 2011; Akdim 2013).

7 The normalized relations with Israel further improve Morocco's standing with the West. Although there is a moderate risk to alienate parts of the Moroccan population over the perceived betrayal of the popular Palestinian cause, Morocco has long had relatively good relations with Israel and the two states have carried on their economic and intelligence cooperation despite the lack of diplomatic relations. 
political competition exists, it is closely regulated and the legal parties do not question the monarchy's superiority. Though Mohamed VI. describes his rule as "technocratic", removed some of his father's elites from major positions (Zerhouni 2004) and introduced "fresh blood" into the apparatus (e.g. his friends and co-students from the collège royal), the overall structure of the Moroccan elites remained intact.

Despite the top-heaviness of Moroccan politics, subnational politics and decentralization deeply penetrate the kingdom's political structure. The new constitution of 2011 was presented not as a reaction to protest, but as a necessary change to accommodate a report by the Consultative Commission on Regionalization. This emphasizes (political) decentralization as a principle of the Moroccan state. It was followed by an (ongoing) ambitious decentralization reform that vastly increased the power of the regional level in 2015 - at least on paper. The monarchy has used decentralization as a tool to uphold and increase its central power since independence. King Mohamed V. encouraged the creation of rural Amazigh parties to neutralize the urban dominance of the Independence Party (Istiqlal) that tried to diminish his powers. Decentralization reforms were moreover used to (successfully) motivate parties to end their boycott of national elections, while upgraded municipal powers made it attractive to compete in local elections. The redrawing of subnational administrative maps, the division of subnational councils or increase of jobs in subnational institutions were used over time to react to crises or to stifle opposition from below (Bouabid and Iraki 2015).

\section{Decentralized power structures: Top-heavy decentralization, sophisticated oversight and new regionalism}

Today, three subnational government tiers form the institutional backbone of decentralization in Morocco: municipalities, provinces and prefectures, as well as regions. All of them are all under the auspices of the Ministry of the Interior (MoI): An elected column (directly or indirectly) accompanies an appointed column of administrative control organs, which represent the state and the king. In 2018, the elected column comprised (1) 1503 municipalities (90\% of which have less than 35,000 inhabitants), (2) 63 provincial councils (rural), and 12 prefectural councils (urban), as well as (3) 12 regional councils (until 2015: 16), whose members were directly elected for the first time in 2015. Subnational councilors are also represented on the national level via indirectly elected members of the second chamber of parliament. 
The councils are flanked by appointed representatives of the MoI on each subnational level: The wali controls the regions, and simultaneously governs one of the provinces and prefectures of the region. He is the nominal representative of the Moroccan king in the regions and controls the decisions of the regional council. The governors on the provincial and prefectural level hold the central position of state control as they oversee the provincial as well as the municipal council decisions (legal state control of elected subnational elites). The governor also leads the agents of state at the local level: The caid (rural) or pasha (urban) acts on the municipal level with close control over local security and local councils. Beneath them, the muqadeem (urban) or sheikh (rural) works as part of everyday administrative life in municipal districts (Houdret and Harnisch 2018; Tafra 2017). This system of administrative oversight (tutelle) stems from French colonial heritage. The center, however, used it to reinforce the ties between the monarchy and the early-independence Moroccan tribes. They were thus integrated into the official state structure, but the bureaucratic selection logic and chain of command from the MoI replaced the tribal origins over time (Charrad 2011; Vollmann et al. 2020; Bouabid and Iraki 2015; Venema and Mguild 2002).

Subnational governance in Morocco has been modified by a host of reforms that increased the de jure influence of decentralized actors (especially on the local level) under the constant dominance of the representatives of the tutelle. In the independent kingdom, the first municipal charter and the elections of 1960 predate the first constitution (1962) and national elections (1963). The elected councils, however, primarily worked as an assisting organ to the caid, functioning as the executive organ of the MoI in the municipalities. Local politics primarily brought the makhzen's "eyes and ears" to the ground. Local politics were a tool to ensure national unity in the young state, "to replace the tribe as the focus of local loyalty and to consolidate monarchic power at the local level" (Bergh 2020, 26). A second municipal charter elevated the position of the local council president, who became the executive organ of the municipality (de jure replacing the caid). The administrative oversight could, however, step in at any point. At the same time slow administrative procedures led to weak capacities for implementing projects. The tax reforms of 1989 improved the funds of Moroccan local governments by entitling them to a fixed share of the VAT, though the skill level and experience of local staff and councilors remained low (Bergh 2020; 2017). While municipalities and provinces / prefectures were mentioned in the constitution of 1963, the new constitution of 1992 also recognized the regions, though their role remained vague. Hassan II had first created seven regions in 1971, between 1997 and the 
new reforms of 2015 Morocco counted 16 regions (Reifeld 2014). Under the rule of Mohamed VI., the decentralization discourse developed a new drive that led to a new municipal charter in 2002, which was amended in 2009. In 2010 a consultative commission on regionalization was formed. The latter's report became the foundation of the post-2011 reforms as well as the discursive anchor for the creation of a new constitution in 2011. The core element of the decentralization reforms in this time was the formal integration of Non-governmental organizations (NGOs) into local governments (possibility for official partnerships between subnational governments and associations and integration into consultative commissions). The reforms also enforced local development plans and reduced the overall number of local councils that had sky-rocketed in the 1990s (Bergh 2017; Bouabid and Iraki 2015).

\section{Neopatrimonial networks and decentralization: New arenas for controlled} competition, training grounds for political actors, dominance through scattered responsibilities

The post-2011 reforms increased the prerogatives, funding (see chapter 5) and salaries of (some) decentralized actors ${ }^{8}$. The regions received the largest formal "upgrade" of all subnational territories and are now responsible for a myriad of tasks (partly overlapping with those of other institutions). Subnational elections have always played a role in Moroccan politics and the local and regional elections of 2015 offered the national political parties a widened arena to compete for influence. Since parliament is widely regarded as relatively powerless, political parties try to influence subnational politics via decentralized councils. As the national elections receive less and less attention by the voters, the importance of subnational elections becomes evident by their higher turnouts in recent history (see Figure 2). Subnational political competition upholds the importance of gaining the support of local notables. Political parties are often centerheavy and lack a decentralized party structure. Therefore, the clientelist "manhunt" to charm local elites into becoming candidates on their party tickets in order to appeal to those notables' networks is widespread and

8 The salaries of all types of council presidents and their vice-presidents have increased considerably. The focus on regions is also visible here as the (now directlyelected) regional presidents receive the same remuneration as national ministers. Regular council members do not receive remuneration which greatly diminishes their capacities to control the presidium and get fully involved in council politics. 
not free of central-state involvement (Tritki 2015; Desrues 2016). Reports of straightforward vote buying are also common (interviews Rabat May 2018). Subnational party politics are often described as largely absent between elections and the perception of a widespread absence of party actors and subnational councilors provokes criticism (interviews Rabat, Ifrane, Sefrou May 2018).

\section{Figure 2: Development of voter turnout in Moroccan elections}

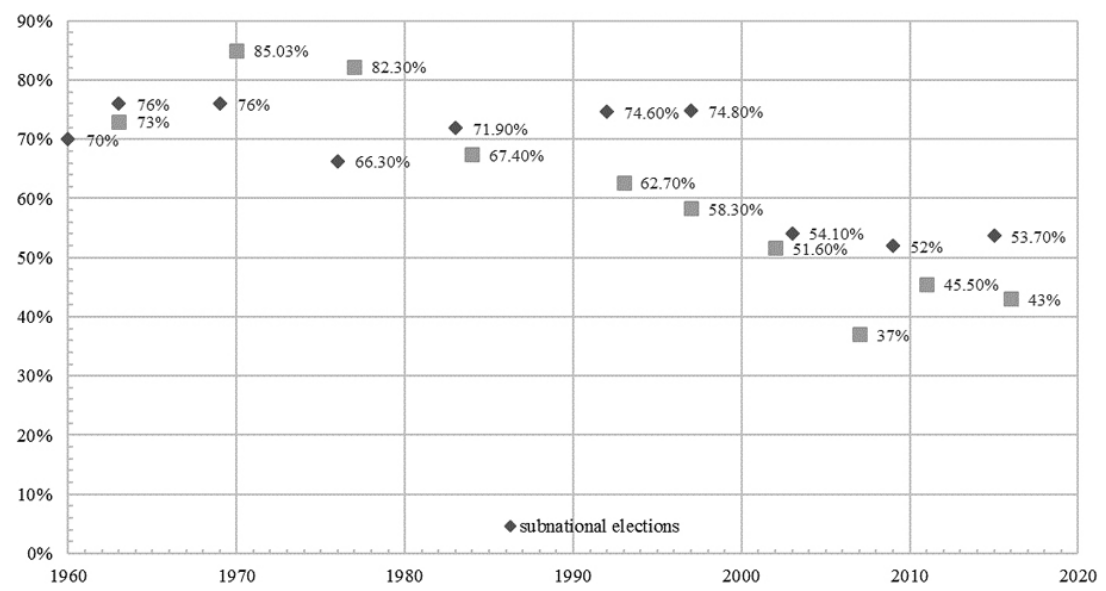

Own depiction. Subnational elections cover local elections for all years and regional elections since 2015 .

Decision-making power, access to funds and even remuneration are concentrated in the presidium of the councils. ${ }^{9}$ As the council presidents (or mayors at the local level) are elected from amongst the council members, the building of council coalitions is necessary. This has helped to restrict the influence of individual parties. As large strata of the party system are coopted "administration parties", the potential for an opposition to the regime in subnational councils is weak. The last elections have seen the relative success of the moderate Islamist Party for Justice and Development (PJD) that can be considered the closest there is to a regime opposition in the legal party spectrum. But its dominance in subnational seats did not

9 Moroccan law does, however, know a remuneration for political group leaders and heads of committees, an arrangement that could foster the development of party structures and capacities. 
translate into a majority of council presidencies (Sturm and Vollmann 2020).

The regional presidencies are mainly controlled by presidents who formerly held ministerial or governmental positions, who have economic ties to the state and the monarchy, or who have had positions in king-led commissions (Sturm and Vollmann 2020; Vollmann et al. 2020; Tafra 2017). A prime example is the regional council president of Fès-Meknès, Mohand Laenser, whose party Mouvement Populaire only won 5 of the 69 regional council seats (7\%, to compare: PJD won 22 seats, PAM 15). Laenser had been active in ministerial positions since 1969 (Tafra 2017). Between 2012 and 2013, he was Minster of Interior, a position closely controlled by the palace.

The background of regional leaders also demonstrates the importance of subnational politics for the central elites: While the career paths of elites in Morocco are mostly considered to be centripetal, the former career paths of regional presidents on the central level as well as of some metropoles' mayors hint to an increasing importance of subnational politics. The Moroccan state has long supported the connection of subnational and national politics by allowing actors to hold both subnational and parliamentary mandates. This has encouraged subnational elites to strive for a role on the national level. Decentralization thus contributes to the renewal of national elites and its formal institutions are targeted both by national and subnational elites (Sturm and Vollmann 2020). The newly upgraded regions are in dire need of attention and well-known actors. Though clearly the focal point of recent reforms, the regional councils lack the de facto power and financial clout to make their mark on Moroccan politics. The nation, the city or village and even to some degree the province or prefecture are rooted in the minds of Moroccan citizens. The regions, however, are an artificial and relatively new institutional level. Accordingly, prominent national figures such as the controversial former regional president of TangérTétouan-Al Hoceima, Ilyas El Omari, a media owner and former president of the palace-related Party for Authenticity and Modernity, can help and increase their visibility. Otherwise, regional councils face the threat of being sidelined by national ministries and the wali (interview Rabat Nov 2018). Though the decentralization laws of 2015 stress the independence of each tier of subnational government and the non-existence of a hierarchy, some municipal actors perceive the regions as a threat. Overlapping tasks and underfunding in combination with the possibility to "upstream" council tasks to higher levels of government contribute to a competition of elected councils (interviews Rabat May 2018, Casablanca, Tanger Nov 2018, Settat Dec 2018). Though agents of the MoI no longer officially con- 
trol council decisions before they are carried out (ex-ante tutelle), its representatives still dominate the councils. They are present at the meetings and the now established ex-post control still upholds an important role for the administration. Especially in rural areas, the representatives of the tutelle, as has been reported, often behave as if they would preside over the councils. The latter often only reluctantly take the initiative without the approval of the king's "eyes and ears" on the ground (interviews Rabat May 2018, Casablanca Dec 2018). The neopatrimonial concentration of power in the hands of the central regime is thus reproduced through the de facto persisting culture of tutelle.

Well-connected local elites (e.g., landowners, businesspersons) who were elected to subnational councils are treated differently and are even courted at times (interviews Rabat, Ifrane May 2018). Moreover, unclear legislation, a delay in its implementation or follow-up legislation, as well as the insufficient training of many councilors contribute to an ongoing dependency of subnational councils on administrative oversight (interviews Rabat, Marrakesh May 2018, Rabat, Casablanca, Nov 2018). The tutelle institutions follow a principle of rotation to decrease their potential for rivalling the central regime, which is a common feature of neopatrimonialism. The high-level state representatives (wali; governor) are presented as non-political actors and indeed are often career bureaucrats. Though the tutelle represents the central state subnationally, other central actors need to be considered in our analysis. Central state initiatives for development that are often connected to the king such as the Initiative for Human Development (INDH), large and prestigious projects as the economic center of the TANGERMED port in Tanger or the restructuring of the Bouregreg delta in the capital region of Morocco are carried out on the national level. Subnational councils need to cooperate with national ministries, or responsibilities are sidelined by the creation of semi-private agencies for the implementation of projects. The "agencification" of large urban planning projects is one increasingly popular mode to circumvent formal institutional settings (sometimes including ministries). This takes political power away from subnational (and sometimes national) institutions in the name of liberalization and a friendly climate for international investment (Amarouche and Bogaert 2019). The dispersion of institutional power ensures that institutional elites cannot get too powerful and organize an opposition to makhzen politics.

Central ministries and their administration, too, are often reluctant to give away power to decentralized or deconcentrated actors. The ongoing process of increased deconcentration (administrative decentralization) aims to strengthen subnational ministerial service provision. As the wali's 
role in the coordination of regional ministerial services has increased by a law passed in late 2018, this could result in a necessary challenge of the reluctance of state administration elites to decentralize (Zaki 2019). We see, however, also the possibility that democratically legitimated elites are sidelined in the process, as the deconcentration law does not deal with subnational councils.

Another group of elites cannot be neglected when dealing with decentralization in Morocco: Civil society organizations. In the past, the regime used local governance reforms to coopt political parties. We now witness the same patterns with civil society organizations which led to the establishment of a codified role in subnational governance (Clark 2018). Subnational councils are obliged to work with NGOs and they are included in official local politics (e.g., subnational planning), or are involved in the provision of subnational services (such as water, electricity, sanitation, transport) (Bergh 2009). The privatization of decentralized competences, such as waste collection, also reinforces the ties between the makhzen and local cronies in the form of public-private partnerships. Lucrative contracts often end up in the hands of economic elites close to the palace (Mekouar 2018, 3).

One the one hand, this disperses the responsibilities of the elected actors among elected other elites. On the other hand, national funds and initiatives that support NGOs condition their funding on regime-friendly or neutral behavior. Subnational councilors are involved in their funding, e.g. through the INDH. This also led councilors to initiate civil society organizations. In the INDH, however, subnational elites are dominated by ministerial representatives and agents of administrative oversight like walis and governors (Clark 2018; Bergh 2017; 2012; Vollmann et al. 2020).

The current state of decentralization in Morocco disperses power and responsibilities between a plurality of political and non-political elites. It both enlarges the circle profiting from state funding (i.e. co-optation), which widens the regime's neopatrimonial networks and increases the obstacles for effective coordination amongst individual actors who could cooperate and potentially pose a threat to the regime.

\section{Elites and decentralization in Jordan}

Center-periphery relations: Highly interwoven, strictly selective

The Hashemite Kingdom of Jordan is a unitary state with a highly centralized structure that revolves around King Abdullah II, who has headed the 
country since 1999. He rules over Jordan with an extensive repertoire of de jure and de facto power, supported by a sprawling web of patron-client relations that reach into both major population groups in Jordan, the Transjordanian and Palestinian communities - not least due to his wife Queen Rania, who is of Palestinian origin. These two groups constitute a major division line in Jordan's political landscape. Transjordanian tribes - or East Bankers - are the original inhabitants of the area and are regarded as the backbone of the monarchy. Accordingly, they occupy a majority of positions in public state institutions and the military. The Palestinian population came to Jordan as refugees after 1948 and 1967. Some individuals, especially from among the Palestinian business elite, became influential players in Jordanian politics over time, but most Palestinians work in the private sector rather than in state institutions. Though they form the majority of the Jordanian population today, Palestinian communities are systematically marginalized by the regime in terms of socio-economic and political participation and development vis-à-vis the Transjordanian population.

Though it is a highly centralized state, Jordan paradoxically is also characterized by the dense personal ties between the center and the periphery, which result from the strong emphasis on tribal and family structures. All decisions of national importance are de facto taken by the king, under consultation of his advisors and the Royal Court, whereupon the Prime Minister and the cabinet execute these decisions. Central elites, including ministers and even the Prime Minister, undergo frequent rotation. The cabinet is typically dissolved whenever it is under fire. Central elites usually represent a certain tribe, family, and locality. Each of Jordan's 12 governorates has a distinct historical background, social and economic features, and a different degree of political influence. The spectrum reaches from governorates with highly heterogenous populations and urban centers like Irbid and Zarqa, to Amman as the majority-Palestinian capital and economic center of the country, to southern rural and majority-Transjordanian governorates such as Karak, Ma'an, and Tafilah. Majority-Transjordanian regions do not, however, guarantee blind loyalty vis-à-vis the regime. Transjordanian populations are amongst the sharpest critics of the center, such as the rural governorates Ma'an and Tafilah who have a history of strong oppositional activities, or Karak with its well-educated, politically influential tribal population. 
Decentralized power structures: From relative autonomy to high central control

Under the supervision of British colonial power, Abdullah ibn Husain I, Emir of the Emirate of Transjordan, integrated the Transjordanian tribes that originally inhabited the area into the state apparatus, in order to ensure their compliance with the newly founded Emirate in 1921. The establishment of municipalities thereby played a significant role, as powerful tribes were granted to rule over them autonomously. Gradually, the sheikhs became key mediators between the new regime and the populace (Alon 2009). This early municipal system marks the origin of modern Jordan's subnational governance system, with far-reaching consequences: The Transjordanian tribes became the traditional support network and main political ally of the monarchy. Ever since, the Hashemites play a sensitive balancing game between the Transjordanian tribes and the majority of the population, which arrived in several refugee waves from Palestine, Iraq, and later Syria (Alon 2009; Clark 2018). Until independence in 1946 and the creation of the Hashemite Kingdom of Jordan, the municipalities had already lost most of their autonomy and political power to the center, but the tribes retained significant influence in the socio-political structure of the country. However, when Jordan slipped into a financial crisis in the 1990s, the following reform course revealed the high socio-political impact of decentralization. Jordan's deeply indebted municipal system was a direct result of low subnational state expenditures in combination with a costly patron-client system that had served the tribal elite for decades (see chapter 5). Neoliberal local governance reforms supported by the International Monetary Fund helped to rearrange Jordan's subnational governance system and to push its efficiency, but they displeased the rural Transjordanian tribes that saw their neopatrimonial networks erode. Meanwhile, the business-oriented Palestinian population in the city centers profited from the measures.

Until today, central state institutions exclusively coordinate all major public service sectors, including education and health. The governorate (regional) level consists of 12 governorates under the jurisdiction of the Ministry of Interior (MoI). The institutions function as the extended arm of the MoI in the periphery and are thus mainly concerned with security issues. At their center is the governor, usually from a military background. He coordinates all state institutions within the governorate, including security forces. All major positions on the governorate level are subject to frequent elite rotation. Governors are replaced every one to two years to keep them from gaining too much power in one location. Individuals with a prestigious position on the governorate level, e.g. the governor or the dis- 
trict manager (mutasarrif), have good chances to reach higher positions in the governorate or the central level in their future careers. Jordan's twelve governorates are further divided into 103 municipalities, which are supervised by the Ministry of Local Administration (MoLA). Only the two economic heavyweights, the Greater Amman Municipality (GAM) and Aqaba Special Economic Zone Authority (ASEZA), are directly supervised by the Prime Minister. Traditionally, municipalities elect a mayor and a municipal council who are responsible for tasks of minor importance, such as urban planning and waste management. ${ }^{10}$ Even if limited, a position in the municipality still comes with a certain degree of prestige and power within the community.

The decentralization reform of 2015, implemented in 2017, barely touched the municipalities, but it established a partly-elected governorate council within each of the 12 governorates (15\% of the governorate council's members are appointed by the council of ministers at the recommendation of the Minister of the Interior). An institution with elected members at Jordan's governorate level was unprecedented. The governorate councils are involved in the decision-making processes regarding major development and infrastructure projects within their territory. Members get to express their preferences and needs. Its executive functions, however, are strictly limited since all measures concerning the implementation or the financing of the projects are exclusively coordinated by central state institutions and their directories in the governorate. Nevertheless, the presence of a new subnational council immediately affected existing elite configurations with repercussions for the outcome of the reform.

\section{Neopatrimonial networks and decentralization: A theatre of reform to uphold} the status quo

While municipalities mostly serve the regime to establish patron-client relations between the center and the local level, and as a platform to represent influential local tribes and families, the governorate institutions traditionally function as central control mechanism in the periphery. The introduction of elected governorate councils by the 2015 decentralization law threw this prevailing local governance system out of balance. According to

10 The exception is the GAM, whose mayor as well as $25 \%$ of the municipal council members are appointed by the Council of Ministers on the recommendation of the Minister of Local Administration (Art. 3, Law on Municipalities 2015). 
official regime statements, the reform had three major goals: (1) organizing capital investments to the governorates more equally, (2) reducing the members of parliaments' (MPs) status as local service providers (this role is common in MENA regimes), and (3) increasing the diversity of members that occupy subnational institutions to better represent the broad population by introducing governorate-wide elections. All three goals inevitably touch existing neopatrimonial relationships between the center and the local level. Capital projects for the governorates were in the past decided behind closed doors in the central ministries, often based on patron-client relations of ministerial staff and without the involvement of the local communities. Hence, the projects often did not serve the broad public, but influential tribes or communities with good ties to central elites profited instead. When decentralization was finally implemented in 2017, local elites rushed to apply as candidates for the governorate council election. ${ }^{11}$ Many hoped to obtain a position of prestige through the membership in the new institution - at least the reform promised to provide each governorate council with a significant amount of funds (an average of 25.8 million USD per governorate in 2018, see chapter 5). After their election however, council members were disappointed to learn about their limited power due to the formal institutional layout on the one hand, but also because of informal practices that further marginalized their position. Municipalities, ministries as well as MPs were to a large degree not supportive of the new institution, as they feared competition by new elites and a loss of their own (informal) power to provide benefits for their clients vis-à-vis the governorate council. Interviews in different locations indicate that ministries frequently refuse to implement the governorate councils' projects, or stop contractors' payments without pre-warning. MPs are rejecting collaboration with the councils that share the same constituencies and, in many locations, municipalities and governorate councils are engaged in an ongoing argument about superiority. As a result, the efficiency of the governorate councils suffers dramatically. In some governorates, the allocated budget for the governorate councils benefits powerful central elites rather than the local communities. For instance, interviews in Karak (Feb 2020) revealed that a majority of the projects in Karak were implemented by companies with ties to the Tarawneh brothers, a highly influential Transjordanian family from Karak. Atef Tarawneh, one of the three brothers and the speaker of parliament between 2013 and 2020, has already been under fire for securing government tenders worth millions for his broth-

11 Municipal and governorate council elections took place on the same day. 
ers' companies during his time in parliament (Al-Shawabkeh and Ghbari 2016). However, in 2020 the Tarawneh brothers were targeted by the latest anti-corruption and tax evasion crackdown of the government, temporarily freezing their assets until the investigation closes (OCCRP 2020). Due to the high amount of pressure upon him, Tarawneh decided not to run for parliamentary elections in November 2020. The incident is a blueprint for how central elites can benefit from decentralization using informal channels including corrupt measures, leaving behind demotivated council members with no intention to run for election again. Depending on the governorate, however, the experiences of the council members differ significantly. To cite a member of the governorate council in Tafilah, a rural, majority-Transjordanian governorate: "Now we are Jordanians". In contrast to other governorates, he enthusiastically reported about the difference the decentralization reform makes for Tafilah, as they now have significantly more central financial support at hand for the development of the governorate. In their opinion, decentralization opened new doors to stretch out their arms to the center.

Reinforced by the practice of competitive clientelism, the lack of a functioning party system, as well as practices such as gerrymandering, elections in Jordan commonly benefit firmly established neopatrimonial elite networks, overwhelmingly based on tribal and family structures. Prior to each parliamentary election between 1989 and $2016^{12}$, a new election law made sure to divide Palestinian and oppositional communities, so that their candidates would have less chances to win mandates. For this purpose, the district managers (mutasarrif) ${ }^{13}$ of each governorate were instructed to draw the constituency borders accordingly. The 2017 municipal and governorate elections did not significantly contribute to more diversity within subnational state institutions either. Independent tribal candidates won over $80 \%$ of the mayoral positions as well as municipal and governorate council seats. There were a few exceptions. For instance, Islamists were very successful in the elections. One prominent example is the Zarqa municipality, that elected Ali Abu al-Sukkar, a former deputy secretary general of the Islamic Action Front (IAF) party as mayor, and seven other members of the IAF into the governorate council (the council has a total of 30 elected members, 8 are appointed). The IAF is the political wing of the

12 The 2020 parliamentary elections took place under the electoral law of 2016.

13 Each governorate is further divided into districts, with a responsible district manager (mutasarrif) each. He is monitoring developments within his territory and reports to the governor. 
Muslim Brotherhood in Jordan and the strongest party behind the Palestinian cause. Although the Jordanian regime tolerates Islamist political representation to some extent, this turnout was not popular within regime circles. Zarqa is the second largest governorate in Jordan, majority-Palestinian and a well-known Islamist stronghold. The governorate has thus traditionally suffered from central financial neglection (for more details see chapter 5). In the end, al-Sukkar's time as mayor of Zarqa was not going to last for long. Several interviews in Zarqa (Jan/Feb 2020) confirmed that the Cities and Villages Development Bank (CVDB) - an institution tied to the Ministry of Local Administration (MoLA) that manages the municipalities' budget and is also in charge of granting loans to them - long denied the Islamist mayor any loans he applied for. Zarqa municipality suffers from high debts and thus, any mayor is practically powerless without additional loans from the center. Furthermore, central ministries prevented alSukkar from attracting a large financial package from Turkey in order to compensate for the absence of central transfers. In May 2019, he resigned due to health issues. The former mayor Emad Momani, who comes from an influential Transjordanian family, took over and was immediately granted loans by the CVDB and allowed to pull other sources of financial support by the ministries. The events around al-Sukkar exemplify the power struggles between central and subnational elites and their impact on the outcome of decentralization. Overall, the Jordanian case points out to the double-edged character of decentralization reforms under neopatrimonialism.

\section{Elites and decentralization in Tunisia}

Center-periphery relations: The shadow of the ancien régime

Tunisia's decentralization project is the only reform of our case selection that is taking place in an environment of a transition to democracy. After the country's independence in 1956 and the abolishment of the Tunisian monarchy in 1957, Tunisia's leading political figure Habib Bourguiba tried to create a strong national state with a predominantly national identity. An active abolishment of tribal structures as well as strict political centralization was the result. Zinedine Ben Ali's authoritarian rule followed this trajectory and established one of the most centralized regimes in the region. Decentralization reforms and subnational governments existed under the strict rule of the center and the ruling party (Neo Destour, later Democratic Constitutional Rally - RCD). Local politics were a means to enforce cen- 
tral party rule and national security. Strong regional discrepancies or even discrimination characterizes the political and economic power distribution in Tunisia. Since Bourguiba's rule, most elites originated from the capital Tunis and the northern coastal regions (Sahel). Their politics let Tunis and the Sahel flourish, while the southern and interior regions are still disfavored peripheries. Though "positive discrimination" is a principle of the post-2011 decentralization reforms to reduce the imbalances between center and periphery, the process is still dominated by central elites and interior and southern regions have not been able to achieve a meaningful redistribution of decentralization funds (see chapter 5).

While Ben Ali was ousted in 2011, regime ties of elites were not brought to an immediate end. Former alliances remained mostly in place and unchallenged (Kchouk and Mamuji 2019). As transitional justice remains a sensitive topic and many civil society activists condemn the widespread amnesties for former regime elites below the highest level of government, old networks still play a role in national and local politics. Central economic elites and most cadres of the old regime's party remained relatively unscathed after the regime change (Kchouk 2017; Günay 2019; Heurtaux 2018; Oubenal and Ben Hamouda 2018).

The old regime had coopted business elites by giving them leeway and preferred access to the otherwise grindingly slow bureaucracy. Elite loyalty under Ben Ali was also ensured by the threat of using arbitrary persecution against them in the case of defections (Günay 2019; Meddeb 2020). Until today, Tunisia's penal code and legislation are a tangled web of obscure, overlapping or even contradictory regulations, which result in an arbitrary application of the law by the authorities. Despite the de facto ties of economic elites to the old regime, with regard to political office, the old regime kept the economic sphere and the setup of political actors separate. During the transition period, economic elites used the opportunity to gain political influence by co-financing political parties or by striving for the immunity that comes with the status of MP (Kchouk 2017; Kchouk and Mamuji 2019; Oubenal and Ben Hamouda 2018). The economic elite networks that survived also affected the fate of regional disparities. The predominantly Northern elites used their contacts to the center to discriminate against contestants from the interior regions (see below). The ministerial services and local administration remained largely unreformed and old contacts remained in place.

Many former regime elites consider themselves apolitical or claim they have been working in the interest of their country not the authoritarian regime (interviews Sousse Oct 2019; Tunis Nov 2019 / Feb 2020). While the constitutional assembly (2011-2014) did restrict the access of members 
of the former ruling party, these provisions were not continued for later elections to keep the political peace during the transition. Estimates suggest, that $80 \%$ of the candidates for local council positions in the first local elections of 2018 had been members of the old regime's ruling party (Yasun 2020).

\section{Decentralized power structures: Strong local governance turnaround halted by central state resistance}

Tunisia has a history of centralized administration with a subnational administrative oversight system (tutelle) that it inherited, as in Morocco, from French colonialism. Administrative oversight developed into a subnational instrument to enforce the rule of the Ministry of Interior and the presidential palace. The tutelle connected a net of central state representatives with a complex layer of administrative tiers. Governors head the governorates and have always been the focal players and connecting agents of the central state, local and regional politics in the country. Though all tutelle administrators are appointed by the Ministry of Interior, Ben Ali oversaw the selection of governors. Under the governors' command are the delegates (mu'tamad) who control the delegations and the 'umda as head of one of the many districts (neighborhood or rural districts). Elected institutions had a far less sophisticated role under the old regime. Regional councils existed in theory, but they were quasi-monopolized by the governor. Only the municipal councils were elected and entitled to choose a mayor amongst the councilors. In practice, the amalgamation of state power and the ruling party led to a dominant position of the RCD in the municipalities (around $80 \%$ of councilors) and the control of all mayors by Ben Ali's party. The district chiefs and delegates were the de facto faces of the regime party on the ground, because they would facilitate contacts to the ministries and disperse party funds to "deserving" citizens (Volpi, Merone, and Loschi 2016; Clark, Dalmasso, and Lust 2019). Moreover, the local heads of administration (secretary generals) were placed under the command of the MoI and were mainly responsible for the formulation of the local budgets. Municipal councils had no financial autonomy between the combined interests of tutelle, the MoI, and party rule (Clark, Dalmasso, and Lust 2019). As the old regime used subnational institutions primarily as a mechanism of control, citizens often perceive municipal politics as a dimension of state security. Mistrust of the state is still widespread, and municipalities are perceived as part of it. The latter fight this "heritage" of the old regime and declare themselves as being separate from the state. Minis- 
terial actors also consider municipalities to be "different" and set apart from the state (interviews Tunis Dec 2019, Feb 2020). This process of alienation leads to conflicts between central state institutions and local councils.

After ousting Ben Ali in the 2010 and 2011 uprisings that sparked in Tunisia's periphery in Sidi Bouzid, the "new" Tunisia opted for a radical change. While the former constitution of 1959 included a taciturn recognition of municipalities and regions (governorates), the 2014 constitution lays special emphasis on decentralization with a whole chapter on the subject. It was drafted under the influence of Tunisian regime outsiders as the electoral rules to the constitutional assembly restricted candidacies of former ruling party members, while opposition parties, especially the Ennahda party whose leaders had partly been exiled under Ben Ali, won a plurality of mandates. The strong emphasis on decentralization in the constitution is thus a clear signal of change from the old system. It also spurned the infamous Ministry of Interior as the symbol for popular suppression both in the capital and through its oversight over governors subnationally (Kherigi 2020b). The newly founded Ministry of Local Affairs and Environment today presides over decentralization. The institutional landscape now formally comprises 350 municipalities, 24 regional councils and districts. However, regional elections have not yet been held. The hyper-centralization of the regime in Tunisia left the new transitional democracy with an especially large burden: Prior to $2014,70 \%$ of the country's area was not municipalized (Tarchouna 2019). Of the now existing 350 municipalities, 86 were newly created after 2014 . The center opted for a slow and long-term implementation of the decentralization law (Local Collectivities Code) of 2018 over the course of 27 years. Though the extensive legal text (400 articles) introduces relatively strong democratic institutions on levels between the local and national governments with quasi-regional and governorate councils, these have not yet been established.

The administrational oversight in the bicephalic system (a legacy of French rule as in Morocco) remains the responsibility of the MoI. While the creation of the Ministry for Local Affairs was a clear break with the strong institutional legacy of the MoI control over local affairs, the development of local governance still relies on the MoI and other ministries. Unfortunately, the inter-ministerial cooperation in Tunisia is traditionally weak, and coalition governments of antagonistic partners have not resulted in clear-cut political agendas (Kherigi 2020b). The enduring statist and centralist political culture in the dealings of state ministries further hinders a meaningful implementation of decentralization in Tunisia (Tarchouna 2019). 
Neopatrimonial networks and decentralization: Old ties, new actors, and cautious central governments

After drafting the constitution, interests and priorities of political elites shifted to the national level. The constant infighting in the Tunisian government prevented a consensual vision of the Tunisian decentralization process. The future of the ambitious decentralization project in the young democracy remains unknown as severe government crises ${ }^{14}$ channel all resources and efforts to the national level. But most actors remain verbally committed to the constitution and its emphasis on subnational governance. (Kherigi 2020b; Bel Haj Amor 2020; interviews Tunis Oct / Nov 2019) A further development of decentralization as well as subnational elections were delayed until 2018, and local governments were appointed by the center far into the transition period. The long delay between drafting the constitution and the first actual decentralization law or the organizing of subnational elections kept the control over subnational politics wholly in the hands of coalition governments, who feared political defeats in the subnational arena (Clark, Dalmasso, and Lust 2019; Belhadj 2016). Local councils associated with the old regime were replaced by special delegations put together by the central state actors in the transition period after 2011. Although they could experiment with new problem-solving strategies and modes of institutional interaction, the delegations were also politicized by the government and used as a tool to uphold central state dominance and power concentration in the hands of the central government (interviews Tunis Oct 2019, Feb 2020). Their chances to withstand national politicization were also conditioned by the support they received from local networks. This reinforces the importance of local level ties. The long-promised local elections were delayed repeatedly, but were finally held in 2018 (Kherigi 2017; Demmelhuber 2018).

The often-delayed decentralization law only passed through parliament shortly before the elections. This made it impossible for candidates to thoroughly familiarize themselves with its content. As the law itself opted for a sequenced implementation and contradicts a plethora of other existing

14 Tunisian governments reshuffled almost every year since 2011. The economic situation remains dire after terrorist attacks brought the vital sector of tourism down in 2015, and the state and politics are met with major distrust by the population. The Tunisian budget is heavily dependent on international loans and the government is encouraged to pursue a course of strict austerity. The consolidation of the Tunisian institutional democracy thus has not been able to grant socioeconomic benefits to the wider public. 
laws, the de facto relationships between local councils, governors, and the central state remain unclear and subject to political power struggles (interviews Tunis, Sousse Oct 2019). The decentralization law grants competences formerly de jure and de facto held by the governors to directly elected regional councils. But since the first direct elections of regional institutions have not yet taken place, in their absence governors as representatives of the MoI try to keep the regional prerogatives "in trust". At the same time, mayors feel that they should inherit regional powers until the councils on these levels are elected since they represent the will of the people locally. This heightens the existing conflicts between these two institutions (Kherigi 2020a; b; interviews Tunis Oct / Nov 2019). The current role of tutelle actors below the governor is relatively unclear (even to some delegates) and likely to diminish considerably when the decentralization law is fully implemented (interviews Tunis, Sousse Dec 2019). A large part of their influence made up the access to the ruling party elites and their funding, a network that broke down after the party's dismantlement. The deployment of special delegations instead of newly elected local representatives, repeated delays in holding local elections and fights regarding the wording of the decentralization's legal code also reflect different political agendas of the then dominating Ennahda and Nidaa Tounis parties. The moderate Islamist Ennahda was forbidden under Ben Ali's regime and many of its prominent figures, including its leader Rached Ghannouchi, came back from exile after 2011. Ennahda became part of the transitional government (Troika, 2011-14), remained a major political power in the governments after the first regular elections (2014-2019), and came first in the fragmented parliament after the 2019 elections. Nidaa positioned itself as the secular counterpart to Ennahda. It also became the new political home to many elites of Ben Ali's regime and was a major coalition partner in the governments between 2014 and 2019, as well as the party of the Tunisian president at the time. The party has since split into several branches.

Political affiliations matter not only nationally but also on the local level. Signs of favor-trading and cooperation are more common when mayors and governors are members of the same political party (Yasun 2020). Moreover, the Ennahda, the only remaining stable party after the elections of 2019, organizes internal trainings, data collection, and inter-level problem solving mechanisms for their own mayors (interviews Tunis Feb 2020). Ennahda also won the race for mayoral positions in Tunisia (131 of 350). However, what was feared by the top-heavy and centralized political parties became reality: Independent candidates were largely successful and gained 127 mayorships. Political parties on the national level are in crisis, 
with the multiple secessions from the Nidaa Tounis party, culminating in the election of the non-affiliated law professor Kais Saied as President (Wolf 2019). Many fear that most parties (besides Ennahda) will not be able to provide party list coverage for subnational elections in the future. This may raise tensions between central and local political actors that are not politically aligned.

While party politics seem to matter for the relationship between councils and tutelle agents, in general governors of all parties are cautious when it comes to rapid change in decentralization and warn against instabilities from below. Their legal role has been substantially downgraded by the decentralization law of 2018, but since they are under the auspices of the MoI and appointed by the Prime Minister (after political negotiations between the ruling parties), they do not always feel bound by the code (interviews Sousse, Tunis, Oct 2019, Tunis Nov 2019, Feb 2020). Some old regime governors still are in office, though "new era" governors including those belonging to the moderate Islamist party Ennahda are in place. Many retain good networks and connections (which some new mayors do not possess) and they control the access to the local police, subnational offices of ministries, and have some influence on the local allocation of funding. Therefore, many mayors are dependent on cooperating with the governors. The local council presidents feel empowered by their democratic legitimacy, whereas the governors can be subject to frequent reshuffling after the numerous government changes in Tunisia. Regional agents of the tutelle (such as the governors) still mainly control governorates from which they do not originate. What used to be a mechanism under the ancien régime to keep local ties of the MoI agents in check has now allowed incidents where governors block development initiatives for the municipalities in the governorate they oversee in order to increase the chances of their own birth places (ICG 2017; Meddeb 2020). Regional reconciliation by decentralization and developmental reallocation is still widely perceived as a zero-sum game.

Struggles for influence also take place inside the local councils. Mayors are the only paid councilor position and they are responsible for the execution of municipal politics. Local councils and mayors also are dependent on their staff (see chapter 5) and their Secretary General (SG), the head of administration. The administration and many SG positions have largely been unaffected by the regime change of 2011. Most Secretary Generals have more experience with local governance than local politicians, and local councils need to rely on their legal and practical knowledge. At times, this leads to power asymmetries between democratically elected representatives and their administration. Mayors with prior experience in the pub- 
lic or local administration tend to fare better in their control over their administration (interviews Sousse, Tunis, Oct 2019). As local elected elites are dependent on the cooperation of the regional governors, ministerial support, and in many cases even their own heads of administration, their position in the unfinished legal environment of decentralization is precarious. This is one factor that contributes to the widespread resignations of individual councilors, local councils as a whole, and mayors in Tunisia. ${ }^{15}$ The peak of local governments' demission in 2019 can be interpreted as an upheaval of the political landscape prior to the parliamentary and presidential elections. This ongoing phenomenon is, however, also an indication for the local governments' sense of impotence in the country's current political system. Local government members and mayors often loose local support if they try to change the longstanding distribution of local funds, or if they try to enforce the law against influential business owners or associations (interviews Tunis Oct 2020, Feb 2020). The relative stability of the relations between old economic elites (located in Grand Tunis and the Sahel), ministries and governors, as well as the reintegration of old regime elites into the political sphere after 2014, has major implications for the new decentralization reforms. Old ties between tutelle agents, economic actors, and ministerial elites remain salient and lead to "unbureaucratic" decisions and project allocations. The old center-periphery conflict remains in place. The northern business elites use their connections with the national administration as well as with the governors to threaten competing new entrepreneurs from the interior regions, or to deny them access to licenses and the national market if they do not cooperate with a business partner from the north (ICG 2017).

15 As mayors are forbidden by law from having other income sources, many former businesspersons, lawyers, or physicians found themselves downgraded in their standards of living after taking up office. Moreover, mass defections of councilors were a strategy to bring down mayors that dominated over their councilors and a means to produce political scandals in advance to the national and presidential elections. 


\section{Elites and decentralization in Egypt ${ }^{16}$}

\section{Center-periphery networks: Turbulent times, yet surprising consistency}

The Egyptian case differs from the other three countries through two major power transitions since 2011. First, long-term President Husni Mubarak was ousted following the protests of 2011 that also terminated the rule of the National Democratic Party (NDP) and its broad national outreach to the local level. In 2013, the military removed democratically elected President Muhammad Mursi from power in a coup. Despite two regime changes within roughly three years, pre-existing patron-client networks between the center and the local levels have remained remarkably stable.

Mubarak's long-term rule was de facto a single-party regime under presidential rule. Thus, central and subnational institutions were filled with NDP members or allies as part of the regime's strategy to handle the periphery and to manage its elites (Martinez-Vazquez and Timofeev 2011). During this period, the decisive intermediary agent between the center and the local levels developed to be what Menza refers to as "lesser notables". People from diverse sociopolitical and economic backgrounds, often of only moderate social origins but extensive networks within their communities, became essential players as middlemen between state institutions and the local populations (Menza 2019). For instance, Hajj Gad Megahed, a merchant and influential member of the Megahed family, which is based in Upper Egypt and deeply involved in Egyptian business and politics, is a well-known figure in the Misr al-Qadimah district in Cairo. He can be considered a lesser notable. Personalities such as him have developed solid patron-client relations with central and regional state officials and are thus commonly consulted in disputes within their community, because they maintain good ties to local police officers and other security agencies (Menza 2013a). In many cases, their ties to the security apparatus and other state authorities are based on bribery and corruption. Oftentimes it is also a sign of the notables' high standing within their families. But their power can reach up to even higher levels: Lesser notables carry a significant role in elections. Not only do they frequently run for municipal or parliamen-

16 The Egyptian case is only based on desk research. Due to the political situation in Egypt and the deteriorating academic freedom, we decided not to conduct fieldwork. Instead, we relied on an evaluation of existing literature, official state channels, media reports and country experts. 
tary elections themselves, but they are also a popular address for MP candidates who aim to win over certain constituencies. In return for services or money, the notables can push candidates by using their influence to secure the votes of a certain district. Through patronage networks like these, the notables contributed to consolidating the NDP's rule in the periphery (Menza 2013b). However, their political affiliation can vary: Under Mubarak, lesser notables were not only affiliated with the NDP, but also with the Muslim Brotherhood (MB) that gained increasing local support during Mubarak's presidency (al-Awadi 2009). Yet, as soon as they became fierce competitors for NDP candidates in the electoral districts, or challenged the fiefdoms of the lesser notables associated to the NDP, the regime reacted with more penetration via the state security apparatus (see e.g. for the district of Imbaba: Abdo 2000). Quite commonly, lesser notables took a rather opportunistic stance and frequently changed their patrons from the NDP to the MB and vice versa, depending on their personal agenda (Menza 2013a). In contrast to more prominent political figures around Mubarak and the NDP, for the most part the lesser notables were able to keep their influence after 2011 due to their respective political independence. Notably, the aftermath of 2011 initiated a race for alliances with lesser notables amongst major political forces (Menza 2019).

After the military coup of 2013 abruptly ended the short rule of Mursi and the MB, which has been labeled a terrorist organization since 2013, the Egyptian state is on a path back to a hyper-centralized system. A short interim period of community activism of so-called popular committees who were - for example in Greater Cairo - filling the void of dissolved NDP networks was rather abruptly ended by massive repression (under the legal umbrella of the state of emergency, Demmelhuber 2019). The military has always played a significant role in Egyptian politics and the administrative state order. However, its influence is likely to increase under as-Sisi's regime and in the absence of a state party with similar tremendous local outreach as the former NDP. Although the 2020 election results indicate a rise of the Mustaqbal Watan Party (Future of the Nation Party), which is affiliated with as-Sisi, it has less implications for local politics.

Decentralized power structures: An ever-failing public service sector, yet no improvement in sight

The roots of modern Egypt's decentralized governance system reach back to the founding of the republic under Gamal Abd an-Nasser after the revolution of the free officers in 1952. Despite several revisions of the local ad- 
ministrative system, Nasser consolidated a centralized state order in which political decision-making over local issues and subnational fiscal policy is predominantly coordinated by central authorities. Under President Anwar as-Sadat (1970-1980), the new constitution of 1971 and a by-law in 1979 (law 43/1979) brought a division of Egypt into 26 governorates that are further subdivided in urban and rural governorates. Essentially, the basic principles of this structure have remained intact until today. The recent constitution of 2014 divides the state into three local administrative units: governorates, cities, and villages - with "legal personality" (Art. 175). The presently existing 27 governorates separate into urban and rural governorates with different administrative subdivisions ${ }^{17}$. The head of each governorate is the governor, who is appointed by the President and provided with a broad spectrum of executive competences. Egyptian governors have extensive de jure and de facto powers. Under Mubarak, the Minister for Local Development (operating under the High Council for Local Administration) was de jure tasked with coordinating all local administrative matters. De facto he was replaced by the Council of Governors, illustrating the governors' power (UNDP and The Institute of National Planning Egypt 2004). Each of the local administrative units further comprises a local executive council filled with appointed staff representing central ministries, and one elected local popular council (LPC) to monitor the work of the executive institutions. The heads of all local units, however, are appointed. By law, the LPCs are entrusted with a supervising function vis-à-vis the heads and executive councils of the local units, but their power is de facto limited to an advisory role (Tadamun 2015). Overlapping responsibilities and a hierarchical order of the subnational levels further diminish the influence of local entities. Consequently, not only does the regime control local entities, but the local entities also monitor other local institutions' performance: Executive councils and LPCs oversee each other's work as well as that of the entities on the lower administrative tiers. The center furthermore administers and closely monitors major public service sectors and subnational fiscal policy. Under Mubarak's rule, the failings of the Egyptian regime to provide a broad range of public services via the state's local administrative units became evident by the fact that civil society organizations began to step in for the regime to support poor and vulnerable populations in many locations across the country. Particularly religious

17 Fully urban governorates (muhafaza) are divided into districts (e.g. Cairo and Alexandria), rural governorates (muhafaza) into regions (markaz), cities (madina), and villages (qariya). 
charity organizations were involved. It was primarily the MB who compensated for lacking government services, but other Islamic or Coptic organizations equally provided aid to marginalized communities. Their freedom to act, however, changed dramatically under as-Sisi's rule (Brechenmacher 2017).

Until the time of writing, the 2014 constitution's provisions still await clarification and implementation through a local administration law. A respective draft law finally made it into parliament in 2018 , but has not been ratified yet. To date, ministries have refrained from implementing several aspects of the constitution. Most significant is the absence of local elections since 2008 and thus, of any elected institution on the subnational level. After the LPCs were dissolved in 2011 to dispose of National Democratic Party (NDP) affiliated elites, they were staffed with appointed personnel.

Neopatrimonial networks and decentralization: Strong bottom-up dynamics and frightened central elites

During Mubarak's rule, the primary opposition of the regime was the Muslim Brotherhood. Over the decades, the Brotherhood had established a strong support base on the local level, not least as a result of its social work in major public service sectors such as health. It was common for the Brotherhood to take over public institutions or professional associations and to convert them into successful entities that eventually served their cause. Hence, when Mubarak announced the advancement of a decentralized state structure in his presidential manifesto of 2005, opinions towards the project were divided in the NDP. Until then, all major positions had been carefully appointed by the center. Most governors were former military generals who demonstrated little interest in serving anyone except their personal clientelist networks (Martinez-Vazquez and Timofeev 2011). The national legislative elections of 2005, in which the Brotherhood won 88 of 444 seats (around 20\%), were an initial indication of how threatening the Muslim Brotherhood's grass-root initiatives could become. As a consequence, the 2006 local elections were postponed until 2008 to avoid the risk of establishing too many Muslim Brothers in elected subnational state institutions. Ahead of the 2008 elections, the Egyptian opposition had to face enormous formal hurdles, because of a series of amendments to 34 articles of the constitution in 2007. This led to widespread social unrest in the 27 governorates (Herzallah and Hamzawy 2008). The amendments were clearly designed to contain the influence of the Muslim Brotherhood, as they banned all political parties with religious frameworks, leaving the 
organization - once again - with no other option than to register their members as independent candidates to run for elections (Brown et al. $2007)^{18}$. Given the strong support the organization could mobilize on the local level, the Mubarak regime further strove to minimize the impact of the Brotherhood's independent candidates. Facing too many formal hurdles to register their candidates prior to the 2008 local elections, the Brotherhood ended up boycotting the elections at the last minute. Clearly, the regime feared that its neopatrimonial networks at the local level would not be strong enough to control the Muslim Brotherhood's influence in an election. With a dramatically low voter turnout of only 5\%, the NDP won the elections by a landslide, occupying over $95 \%$ of the seats (Herzallah and Hamzawy 2008). In the end, formal-legal measures helped to contain the regime-threatening dynamics of local politics and to uphold proregime majorities within subnational institutions. The 2008 local elections would become the last ones held in Egypt up to this day.

When the Arab uprisings spilled over to Egypt in 2011, the country was about to enter a period of extraordinary uncertainty. With a history of grass-roots organizations assuming state tasks, the population became active again. In Cairo and Gizeh for instance, neighborhoods formed local popular committees that helped organize everyday life and needs in the absence of a functioning state. Throughout 2011 and 2012, these committees were successful in forcing local state agents and institutions to comply with the communities' demands. Before that, local state institutions would often be unresponsive to any incoming directives or requests. But circumstances changed since they were no longer protected by the central state and the NDP. Increasing repression by the as-Sisi regime since 2013 gradually marginalized their freedom to act and diminished their influence at the local level. Simultaneously, old local elites from the Mubarak regime often coopted the new local political actors, which further limited the autonomy of this local activism (Harders and Wahba 2017). In other locations, local committees had been established by old local NDP affiliates and their patron-client networks (Meehy 2017). The Egyptian population proved its ability to compete with state institutions in terms of public ser-

18 In addition, while the amendments facilitated the legal framework for political parties to nominate a candidate to run for presidential elections, they also set out conditions for independent candidates that were almost impossible to fulfil. Inter alia, independent presidential candidates were now obliged to register the support of a minimum of 230 members of parliament and local councils, a provision which raised the political significance of elected local councils (Brown et al. 2007). 
vice provision on several occasions. But as-Sisi's harsh crackdown on civil society activism has led to an end of almost all of these activities (Meehy 2017). Since the crackdown also targets religious charity organizations that played an important role in public service delivery under Mubarak, the situation of peripheral populations may have worsened (Ismail 2019; Brechenmacher 2017).

Seven years after the coup, as-Sisi is still in the process of consolidating his power (Noll 2019). He has upheld the state of emergency since 2016. The regime remains hesitant to implement a local governance law that could destabilize the current situation. The ratification of a new law would urge the regime to hold local elections. This constitutes a risk to the as-Sisi regime, due of the absence of a party that keeps strong ties to the periphery as Mubarak's NDP had done. The 2014 constitution formally limits the LPC's power by stipulating that elected local councils' decisions should be final, but executive authorities may interfere "to prevent the council from overstepping these limits, or causing damage to the public interest or the interests of other local councils" (Art. 181). For now, committing to meaningful decentralization poses too much of a threat to central elites and their power to control the periphery. According to several sources, as-Sisi continues to hinder a new local administration law due to an internal struggle between several intelligence agencies (Mada Masr 2020).

So far, as-Sisi relies on his military networks to govern the periphery. In strategically important governorates including Red Sea, al-Ismailia, Port Said, Suez as well as North and South Sinai, almost all governors since the mid-1990s came from military backgrounds. In other governorates the governors' backgrounds varied between the military and other non-security-related professions. In some governorates including Cairo, al-Sharqiya and Asyut, governors rarely had ties to the military. During the first governor reshuffle since as-Sisi's inauguration in 2015, only three out of 17 new governors had a background as military generals. The other 14 governors included several university professors, judges, or government officials. No women or Copts were among them (Atlantic Council 2015), nevertheless this may be interpreted as a good will message to the international community, because a few years later the situation changed. The number of military generals appointed as governors increased considerably after 2017/2018, even in governorates such as Cairo, al-Sharqiya and Asyut, who are used to non-military governors. In November 2019, 11 out of 16 new governors had held senior positions in the security sector or the army. For instance, General Muhammad El-Sherif, who had formerly served as security chief of Giza and Alexandria (Al Tawy 2019), replaced the governor of Alexandria (a professor of engineering). Simultaneously, for the first time 
in Egyptian history, as-Sisi named Nadia Ahmed Abdou Saleh, a Muslim woman, as governor of Baheira in 2017. In 2018, he took one-step further by appointing Manal Awad Mikhael, a Coptic woman, as governor of Damietta (Shaban 2018). This may have been an attempt to appease international donors as well as to coopt Coptic communities. In July 2020, asSisi announced a new law (Law No. 165 of 2020) that allows for the appointment of a military advisor and a number of assistants to each governorate nominated by the Minister of Defense. The new advisors shall report to the Ministry of Defense and are instructed to handle security affairs and problems within the communities, thereby coordinating with the respective subnational authorities. They are also allowed to attend meetings of the executive councils if they wish. Critical voices rate this as an attempt to gain control over the periphery by further militarizing subnational institutions (Al-Monitor 2020; Anadolu Agency 2020). However, the new law may not only be the result of security questions, but also of economic considerations. The presence of a military advisor in each governorate will open up new possibilities for companies affiliated with the military to land large-scale projects (Al-Monitor 2020). The Egyptian military has been involved in the private business sector for decades, but recent legal changes under as-Sisi's rule have made it easier for military companies or private companies owned by former military officers to obtain government contracts (Adly 2014). According to a source from the Ministry of Military Production, the revenues of 20 military companies reached around 840 million USD in $2018 / 2019$, which is a five times higher amount than in 2013/2014 (Dunne 2018).

Government corruption at the local level has taken over new dimensions ever since the local administrative institutions are exclusively filled with appointed staff and no elected council monitors their work (Rabie 2019). Meanwhile, as-Sisi created his own administrative capital city, Wedian, a gated zone from where he rules the country and is surrounded by hand-picked military officers and state servants. Wedian is located far from Cairo and possible threats of popular movements (Dunne 2018). The largescale protests of 2019 prove that the Egyptian population is growing increasingly impatient and is now ready to openly express socioeconomic grievances, despite the power of as-Sisi's extensive repression apparatus. These developments indicate that as-Sisi's plan to rely on repression to consolidate his rule is beginning to erode and will need some reconsiderations in order to uphold legitimacy in the long term (Demmelhuber 2019). Overall, the case of Egypt demonstrates the power of bottom-up dynamics and grass-roots organizations vis-à-vis the regime when it comes to local 
public service provision and highlights the sensitivity of decentralization under neopatrimonialism.

\section{Conclusion: Smart vs. old-fashioned autocrats and the shadows of the past}

Our analysis of Morocco, Jordan, Tunisia, and Egypt reveals how different strata of elites - reaching from the center down to the local level - use formal and informal institutions that make up a decentralized state structure to maintain or widen their influence, resources, and power. The empirical analysis also clearly illustrates the fine line between the opportunities and threats of decentralization under neopatrimonialism. In all cases, the design of decentralization formally and informally benefits the regime. However, under certain circumstances regimes are hesitant to commit fully to the legal framework as it holds potential to backfire. Over the past decades, the monarchies Morocco and Jordan, who survived the Arab protests relatively unharmed compared to Tunisia and Egypt, have spanned a solid network of patron-client relations between the center and the periphery via subnational state institutions. The Jordanian regime thereby pays close attention to the sensitive management of Transjordanian and Palestinian communities - overwhelmingly to the benefit of Transjordanian tribes. Subnational actors in Morocco are also carefully divided and controlled by a net of state agents whose dominance over subnational councils is unbroken. While party elites engage actively in elections and political struggles, they are dependent on alliances with local notables, party coalitions and deference to the monarchy and its national and subnational representatives. The codified inclusion of NGOs and the dominance of the central state and its development initiatives has broadened the strata of elites that get access to state resources. Both kingdoms furthermore established formal structures that regulate the interplay between elected and appointed subnational institutions in favor of the appointed tiers. These respond to the instructions of the central ministries. Opportunities for the promotion to higher levels in the public state apparatus function as incentives that draw ambitious elites into the subnational state institutions. Though both countries grant some minor autonomy to subnational institutions, underlying formal and informal practices can be activated at any time to limit the power of lesser institutions if necessary. Elite rotation between major subnational positions to contain the influence of certain individuals is a common practice in all four countries, especially concerning the governors with their extensive powers. 
Even after major power transitions in Tunisia and Egypt, central elites still use decentralization for their own political purpose. While Mubarak used the NDP and its clientelist networks to control the periphery in Egypt, as-Sisi increasingly consolidates his power over the periphery by militarizing subnational institutions in the absence of a state party. The case also illustrates how grass-root organizations and civil society activism can benefit from decentralization if the central state shows weaknesses in terms of public service provision. The Muslim Brotherhood was able to expand its influence at the local level and eventually posed a serious challenge to the regime. To this day, the as-Sisi regime suffers from the consequences. For this reason, repression of subnational activism has grown significantly and local elections still have not taken place after almost seven years of rule. While Egypt's plans to decentralize the state may never have been entirely legitimate in the Western understanding of this policy, under as-Sisi the project is likely to have reached a dead end. Tunisia is receiving much international attention for its transition to democracy, but the new decentralization project enshrined in the 2014 constitution still has a long way to go. Competition and diverging views of old and new elites have been a burden on the new state from the beginning. The same is true for the decentralization project. The sudden move from Ben Ali's hyper-centralized state order towards decentralization is taking time to unfold. Like Egypt, Tunisia is hesitant to fully commit to subnational elections and still stalls those for the regional councils. Though highly ambitious, the Tunisian decentralization project lacks the support of ministerial elites in the center and a clear government vision. The central government parties were hesitant to move forward with decentralization laws as well as local elections. They were threatened by the possibility that unaligned candidates would succeed. Indeed, independent candidates were very successful, and their rise was an overture to the implosion of the national party system. Local elected elites are dependent on the cooperation with regional governors, ministerial support, and in many cases even their own heads of administration. Their current position in the unfinished legal outline of decentralization is precarious. The new ministry in charge of decentralization lacks the power to implement the reform on its own. The success of the process would depend on the cooperation of large ministries, especially the Ministry of Interior and the Ministry of Finance and their agents. As inter-ministerial coordination is deficient, local political elites are left hanging in a web of conflicting laws and provisions.

In all four cases, the structure of elite networks and their respective behavior also affects the de facto outcome of decentralization vis-à-vis its legal outline. Jordan and Morocco are playing a sensitive balancing game be- 
tween the wish to appease the international community as reformers and to successfully manage socio-political and economic cleavages on the ground. A decentralization reform deeply interferes with a country's patron-client structure and its outcome depends on central and subnational elites' reaction. Competitive clientelism and gerrymandering that accompany subnational elections, as well as elite capture, easily twist the logic of decentralization reform. With this background, the result of Jordan's 2017 decentralization elections was less than surprising: The majority of seats mirrored the same tribal structures as those at the central level. Over the past decades, the neopatrimonial structures of the country had already consolidated an unequal distribution of public state resources amongst the governorates (see chapter 5). Elite capture and the ministerial employees' lack of willingness to cooperate (for fear of losing their clientelist networks vis-à-vis the new governorate councils) further limits the effectiveness of the entire process. The same can be witnessed in the Moroccan case. The kingdom excels in the creation of participative subnational institutions that carry democratic legitimation, a net of development programs, liberalized institutions, and means to promote the work of NGOs, while carefully pitting them against each other so that no single actor is able to gain too much influence. Decentralization in Morocco provides additional access to state resources and offices. Both national political elites and the new strata of elites (e.g. NGOs) partake in them. They compete for influence, but all remain dependent on the central regime and its oversight. Tunisia's decentralization process began as a powerful and conscious turn away from old centralist structures, edging toward a democratic transition. However, the process soon fell victim to central power relations. Instead of moving the legal and electoral reform process forward, the (democratic) governments used appointed special delegations to govern the local body politic. The delegations were subject to political infights and contentions, both at the national and the local level. The central governments' attention shifted to more pressing national problems and ongoing economic difficulties. If the vast national ministries are not profoundly restructured in the future, the success of decentralization is doubtful. Ministerial elites and governors are still more powerful and better connected. They thus are the primary determinants of the success of local political elites in their cooperation with the center. In this point, as-Sisi's rule differs significantly from the other three cases. Due to security concerns and a re-centralization process since 2014, the regime is actively holding back the execution of certain formal features of decentralization as laid down in the constitution of 2014. First and foremost, the regime has hindered holding subnational elections, and refused to allow a new local administration law to pass through parliament. As a 
consequence of neopatrimonialism and the absence of elected institutions to monitor the executive tiers, arbitrary procedures and corruption on the subnational levels are increasing, while local public service provision is deteriorating.

Our comparison of Morocco, Jordan, Tunisia, and Egypt illustrates that a genuine decentralization process cannot simply rely on technicalities or an apolitical delegation of tasks. A successful implementation requires sophisticated modifications of a country's institutional landscape as much as it requires a fundamental change in the structure and the mentality of central state elites and their patron-client networks. If neopatrimonial structures are too dominant, they twist the logic of a decentralized state structure and reduce its effectiveness dramatically.

\section{References}

Aalen, Lovuse, and Ragnhild L. Murias. 2018. Manipulating Political Decentralization. Africa's Inclusive Autocrats. New York: Routledge.

Abdo, Geneive. 2000. No God but God. Egypt and the Triumph of Islamism. Oxford: Oxford University Press.

Adly, Amr. 2014. "The Future of Big Business in the New Egypt." Carnegie Middle East Center. Accessed March 11, 2021. https://carnegieendowment.org/files/big_ business_egypt.pdf.

Akdim, Youssef Aït. 2013. "Grandes Familles Marocaines: qui Gère Vraiment le Royaume?”Accessed March 11, 2021. https://www.jeuneafrique.com/136586/poli tique/grandes-familles-marocaines-qui-g-re-vraiment-le-royaume/.

Al-Awadi, Hesham. 2009. "A Struggle for Legitimacy: the Muslim Brotherhood and Mubarak, 1982-2009." Contemporary Arab Affairs 2 (2): 214-228. doi: 10.1080/17550910902854015.

Al-Tawy, Ayat. 2019. "Egypt Names 16 Provincial Governors Ahead of Anticipated Ministerial Reshuffle.” Accessed September 17, 2020. http://english.ahram.org.e g/NewsContent/1/64/356726/Egypt/Politics-/Egypt-names--provincial-governorsahead-of-anticip.aspx.

Al-Monitor. 2020. "Appointing Military Advisers to Oversee Civil Life in Egypt Stirs Anger.", Al-Monitor, August 9. Accessed September 11, 2020. https://www. al-monitor.com/pulse/originals/2020/08/egypt-law-military-role-civil-life-ministri es.html.

Alon, Yoav. 2009. The Making of Jordan: Tribes, Colonialism and the Modern State. London, New York: I.B. Tauris.

Al-Shawabkeh, Musab, and Muhammad Ghbari. 2016. "Jordanian MPs Pocket Tenders in the Millions.” Amman Net, September 19. Accessed March 11, 2021. https://ammannet.net/english/jordanian-mps-pocket-tenders-millions. 
Amarouche, Maryame, and Koenraad Bogaert. 2019. "Reshaping Space and Time in Morocco: The Agencification of Urban Government and its Effects in the Bouregreg Valley (Rabat/ Salé).” Middle East - Topics \& Arguments 12 (1): 44-54. doi: 10.17192/meta.2019.12.7934.

Anadolu Agency. 2020. "Egypt Appoints Military Advisor for Each Governorate." Anadolu Agency, July 29. Accessed March 11, 2021. https://www.aa.com.tr/en/m iddle-east/egypt-appoints-military-advisor-for-each-governorate/1926413.

Atlantic Council. 2015. "Who Are Egypt's New Governors?" Atlantic Council, February 7. Accessed March 11, 2021. https://www.atlanticcouncil.org/blogs/me nasource/who-are-egypt-s-new-governors/.

Bel Haj Amor, Mohamed Lamine. 2020. "Local Governance in Tunisia - A Holistic Decentralization Strategy.” In Tunisia's Fragile Democracy, edited by Dina Fakoussa and Laura Lale Kabis-Kechrid, 13-16. Berlin: DGAP.

Belhadj, Souhail. 2016. "De la Centralisation Autoritaire à la Naissance du «Pouvoir Local »: Transition Politique et Recompositions Institutionnelles en Tunisie (2011-2014).” Social Science Information 55 (4): 479-494. doi: $10.1177 / 0539018416658154$.

Bencheikh, Souleiman. 2011. “Maroc: le Clan El-Fassi.” L'Express, October 1. Accessed March 11, 2021. https:/www.lexpress.fr/actualite/monde/afrique/maroc-1 e-clan-el-fassi_1036628.html.

Bergh, Sylvia I. 2009. "Traditional Village Councils, Modern Associations, and the Emergence of Hybrid Political Orders in Rural Morocco.” Peace Review 21 (1): 45-53. doi: 10.1080/10402650802690060.

Bergh, Sylvia I. 2012. “'Inclusive' Neoliberalism, Local Governance Reforms and the Redeployment of State Power: The Case of the National Initiative for Human Development (INDH) in Morocco.” Mediterranean Politics 17 (3): 410-426. doi: 10.1080/13629395.2012.725304.

Bergh, Sylvia I. 2017. The Politics of Development in Morocco: Local Governance and Participation in North Africa. London: I.B. Tauris.

Bergh, Sylvia I. 2020. "Morocco's Decentralization Experience." In The Dynamics of Decentralization in the MENA: Processes, Outcomes, and Obstacles, edited by Marwa Shalaby, Chagai Weiss, Ellen Lust, Kristen Kao, Erik Vollmann, Sylvia I. Bergh, Ezra Karmel, Miriam Bohn, Intissar Kherigi and Zeynep Kadirbeyoglu, 23-39. Gothenburg: GLD.

Bouabid, Ali, and Aziz Iraki. 2015. "Maroc: Tensions Centralisatrices." In Local Governments and Public Goods: Assessing Decentralization in the Arab World, edited by Mona Harb and Sami Atallah, 47-92. Beirut: LCPS.

Bratton, Michael, and Nicolas van de Walle. 1997. Democratic Experiments in Africa. Regime Transitions in Comparative Perspective. Cambridge: Cambridge University Press.

Brechenmacher, Saskia. 2017. Institutionalized Repression in Egypt. In Civil Society Under Assault: Repression and Responses in Russia, Egypt, and Ethiopia, edited by Saskia Brechenbacher. Washington, D.C.: Carnegie. 
Brown, Nathan J., Michele Dunne, and Amr Hamzawy. 2007. "Egypt's Controversial Constitutional Amendments.” Carnegie Endowment. Accessed March 11, 2021. https://carnegieendowment.org/files/egypt_constitution_webcommentary 01.pdf.

BTI. 2020. “Bertelsmann Transformation Index. Atlas.” Accessed March 11, 2021. https://atlas.bti-project.org/.

Cammack, Diana, Fred Golooba-Mutebi, Fidelis Kanyongolo, and Tam O'Neil. 2007. Neopatrimonial Politics, Decentralisation and Local Government: Uganda and Malawi in 2006. London: Overseas Development Institute.

Charrad, Mounira M. 2011. "Central and Local Patrimonialism: State-Building in Kin-Based Societies." The Annals of the American Academy of Political and Social Science 636: 49-68.

Clapham, Christopher. 1985. Third World Politics. An Introduction. Abingdon: Routledge.

Clark, Janine A. 2018. Local Politics in Jordan and Morocco. Strategies of Centralization and Decentralization. New York: Columbia University Press.

Clark, Janine A., Emanuela Dalmasso, and Ellen Lust. 2019. "Not the Only Game in Towns: Explaining Changes in Municipal Councils in Post-revolutionary Tunisia." Democratization 26 (8): 1-20. doi: 10.1080/13510347.2019.1641087.

Clark, Janine A. 2018. Local Politics in Jordan and Morocco. Strategies of Centralization and Decentralization. New York: Columbia University Press.

Collado, Ángela Suárez, and Raquel Ojeda García. 2015. "The Effects of the Moroccan Advanced Regionalization Process in Western Sahara." Transmodernity: Journal of Peripheral Cultural Production of the Luso-Hispanic World 5 (3): 76-98.

Daadaoui, Mohamed. 2011. Moroccan Monarchy and the Islamist Challenge. New York: Palgrave Macmillan.

Demmelhuber, Thomas. 2018. Die politische Ordnung in Tunesien und die Beziehungen mit der EU seit 2011: Dezentralisierung als Blaupause? IEP Reserach Paper No. 03/18. Berlin: IEP.

Demmelhuber, Thomas. 2019. "Ausnahmezustand als Herrschaftstechnik? Ägypten und die Politischen Umbrüche seit 2011.” Zeitschrift für Menschenrechte/journal for human rights 13 (2): 57-70.

Demmelhuber, Thomas, Roland Sturm, and Erik Vollmann. 2020. "Decentralization in the Arab world: Conceptualizing the Role of Neopatrimonial Networks." Mediterranean Politics 25 (4): 499-521. doi: 10.1080/13629395.2018.1559 391.

Desrues, Thierry. 2016. "Le PJD en Ville, le PAM à la Campagne. Le Multipartisme Marocain à l'Épreuve de la Bipolarisation.” L'Année du Maghreb 15 (2016): 229254.

Dunne, Michele. 2018. "Sisi Builds a Green Zone for Egypt." Carnegie Endowment, November 27. Accessed March 11, 2021. https://carnegieendowment.org/ 2018/11/27/sisi-builds-green-zone-for-egypt-pub-77803. 
Eaton, Kent, Kai Kaiser, and Paul Smoke. 2010. The Political Economy of Decentralization Reforms. Implications for Aid Effectiveness. Washington, DC: World Bank.

Eisenstadt, Samuel N. 1973. Traditional Patrimonialism and Modern Neopatrimonialism. London: Sage.

Erdmann, Gero, and Ulf Engel. 2007. "Neopatrimonialism Reconsidered: Critical Review and Elaboration of an Elusive Concept." Commonwealth \& Comparative Politics 45 (1): 95-119. doi: 10.1080/14662040601135813.

Gerschewski, Johannes. 2013. "The Three Pillars of Stability: Legitimation, Repression, and Co-optation in Autocratic Regimes.” Democratization 20 (1): 13-38. doi: 10.1080/13510347.2013.738860.

Günay, Cengiz. 2019. The New-Old Elites and their Relations with the EU: The Cases of Egypt and Tunisia. Barcelona: IEMed.

Harb, Mona, and Sami Atallah. 2015. "An Assessment of Decentralization and Service Delivery in the Arab World." In Local Governments and Public Goods: Assessing Decentralization in the Arab World, edited by Mona Harb and Sami Atallah, 229-234. Beirut: LCPS.

Harders, Cilja, and Dina Wahba. 2017. "New Neighborhood Power" The Century Foundation, February 14. Accessed March 11, 2021. https://tcf.org/content/repor t/new-neighborhood-power/?session=1\&session=1.

Helmke, Gretchen, and Steven Levitsky. 2004. "Informal Institutions and Comparative Politics: A Research Agenda." Perspectives on Politics 2 (4): 725-740. doi: 10.1017/S1537592704040472.

Herzallah, Mohammed, and Amr Hamzawy. 2008. "Egypt's Local Elections Farce. Causes and Consequences.” Carnegie Endowment. Accessed March 11, 2021. https://carnegieendowment.org/files/egypt $\% 27$ s_local_elections_final2.pdf.

Heurtaux, Jérôme. 2018. "Elites and Revolution: Political Relegation and Reintegration of Former Senior Government Officials in Tunisia.” Historical Social Research 43 (3): 98-112. doi: 10.12759/hsr.43.2018.4.98-112.

Heydemann, Steven. 2007. "Upgrading Authoritarianism in the Arab World." The Saban Center for Middle East Politics Analysis Paper (13). Washington, D.C.: Saban.

Hinnebusch, Raymond. 2012. "Syria: from 'Authoritarian Upgrading' to Revolution?” International Affairs (Royal Institute of International Affairs 1944-) 88 (1): 95-113.

Hissouf, Abdellatif. 2016. "The Moroccan Monarchy and the Islam-oriented PJD: Pragmatic Cohabitation and the Need for Islamic Political Secularism.” All Azimuth 5 (1): 43-56.

Houdret, Annabelle, and Astrid Harnisch. 2018. "Decentralisation in Morocco: a Solution to the 'Arab Spring'?" The Journal of North African Studies 24 (6): 1-26. doi: 10.1080/13629387.2018.1457958.

Hyden, Goran, Julius Court, and Kenneth Mease. 2004. Making Sense of Governance: Empirical Evidence from 16 Developing Countries. Boulder, CO: Lynne Rienner. 
ICG. 2017. La Transition Bloquée: Corruption et Régionalisme en Tunisie. Brussels: International Crisis Group.

Ismail, Zenobia. 2019. "Effectiveness and Legitimacy of State Institutions in Egypt.” Accessed March 11, 2021. https://opendocs.ids.ac.uk/opendocs/bitstream /handle/20.500.12413/14628/621_Legitimacy_of_the_State_and_Institutions_in _Egypt.pdf?sequence=1\&isAllowed=y.

Johnson, Craig, Priya Deshingkar, and Daniel Start. 2003. "Grounding the State: Poverty, Inequality and the Politics of Governance in India's Panchayats." Overseas Development Institute (Working Paper 226). Accessed March 11, 2021. https://www.odi.org/sites/odi.org.uk/files/odi-assets/publications-opinion-files/7 8.pdf.

Kchouk, Bilel. 2017. "Les « Anciennes » Élites Économiques et le Changement de Régime en Tunisie : de l'Incertitude vers la Consolidation Politico-économique des Positions.” Politix 120 (4): 157-178. doi: 10.3917/pox.120.0157.

Kchouk, Bilel, and Aaida Mamuji. 2019. "Regime Change and Elite Behaviour: the Case of the 2010-2011 Tunisian Uprisings." The Journal of North African Studies 24 (6): 896-913. doi: 10.1080/13629387.2018.1466467.

Kherigi, Intissar. 2017. "Local elections in Tunisia: The Last Hope for Real Change. Middle East Eye on 6 Oct 2017.” Middle East Eye, October 21. Accessed October 10, 2020. http://www.middleeasteye.net/columns/local-elections-tunisia-last-hop e-real-change-1511501287.

Kherigi, Intissar. 2020a. "Decentralisation: The Search for New Development Solutions in the Arab World's Peripheries.” Arab Reform Initiative, January 21. Accessed February 19, 2020. https:/www.arab-reform.net/publication/decentralisat ion-the-search-for-new-development-solutions-in-the-arab-worlds-peripheries/.

Kherigi, Intissar. 2020b. "Tunisia's Decentralization Reforms: The Gap between Ideas and Implementation." In The Dynamics of Decentralization in the MENA: Processes, Outcomes, and Obstacles, edited by Chagai Weiss, Marwa Shalaby, Ellen Lust, Kristen Kao, Erik Vollmann, Sylvia I. Bergh, Ezra Karmel, Miriam Bohn, Intissar Kherigi, and Zeynep Kadirbeyoglu, 54-66. Gothenburg: GLD.

Lagarde, Dominique, Souleiman Bencheikh, and Myriem Khrouz. 2011. "Les grandes familles du Maroc.” L'Express, October 1. Accessed March 11, 2021. https:/www.lexpress.fr/actualite/monde/afrique/les-grandes-familles-du-maroc_1 035530.html.

Lust, Ellen. 2009. "Competitive Clientelism in the Middle East." Journal of Democracy 20 (3): 122-135.

Mada Masr. 2020. "Sisi Seems to Reverse position on Local Council Elections, Speaker Blames 'Deep State' for Delay of Bill in Parliament.” Mada Masr, January 22. Accessed March 11, 2021. https://www.madamasr.com/en/2020/01/22/fe ature/politics/sisi-seems-to-reverse-position-on-local-council-elections-speaker-bla mes-deep-state-for-delay-of-bill-in-parliament/.

Martinez-Vasquez, Jorge, and Andrey Timofeev. 2011. "Decentralizing Egypt: Not Just Another Economic Reform." In Decentralization in Developing Countries. Global Perspectives on the Obstacles to Fiscal Devolution, edited by Jorge MartinezVasquez and Francois Vaillancourt, 389-430. Cheltenham: Edward Elgar. 
Meddeb, Hamza. 2020. "Tunisia's Geography of Anger: Regional Inequalities and the Rise of Populism.” Carnegie Endowment, February 19. Accessed March 11, 2021. https://carnegie-mec.org/2020/02/19/tunisia-s-geography-of-anger-regionalinequalities-and-rise-of-populism-pub-81086.

Meehy, Asya. 2017. "Governance from Below Comparing Local Experiments in Egypt and Syria after the Uprisings." In Arab Politics Beyond the Uprisings: Experiments in an Era of Resurgent Authoritarianism, edited by Thanassis Cambanis, and Michael W. Hanna, 1-18. New York City: The Century Foundation.

Mekouar, Merouan. 2018. "Beyond the Model Reform Image. Morocco's Politics of Elite Co-Optation.” In GIGA Focus 3/2018. Hamburg: German Institute of Global and Area Studies (GIGA).

Menza, Mohamed Fahmy. 2013a. "Neoliberal Reform and Socio-Structural Reconfiguration in Cairo's Popular Quarters: The Rise of the Lesser Notables in Misr Al Qadima." In The Redeployment of State Power in the Southern Mediterranean, edited by Sylvia I. Bergh, 20-37. New York: Routledge.

Menza, Mohamed Fahmy. 2013b. Patronage Politics in Egypt: The National Democratic Party and Muslim Brotherhood in Cairo. New York: Routledge.

Menza, Mohamed Fahmy. 2019. “Cairo's New Old Faces: Redrawing the Map of Patron-Client Networks Against the Background of the January 25 Revolution and the 2015 Elections." In Clientelism and Patronage in the Middle East and North Africa, edited by Laura Ruiz de Elvira, Christoph H. Schwarz, and Irene Weipert-Fenner, 98-117. New York: Routledge.

Noll, Jessica. 2019. "Fighting Corruption or Protecting the Regime? Egypt's Administrative Control Authority.” Project on Middle East Democracy, February 06. Accessed March 11, 2021. Washington, D.C.: POMED.

OCCRP. 2020. "Cash-Strapped Jordan Targets Premium Tax Evaders.” Organized Crime and Corruption Reporting Project, July 17. Accessed March 11, 2021. https://www.occrp.org/en/blog/12775-cash-strapped-jordan-targets-premium-taxevaders.

Oubenal, Mohamed, and Houda Ben Hamouda. 2018. The Political Economy of Business Elites in Tunisia: Actors, Strategies and Identities, Economic Research Forum Working Papers No. 1273. Giza: Economic Research Forum.

Rabie, Hossam. 2019. "Egypt Plans to Reinstate Municipal Oversight Councils." Al-Monitor, November 1. Accessed March 11, 2021. https://www.al-monitor.co $\mathrm{m}$ /pulse/originals/2019/10/egypt-local-council-elections-municipalities-corruptio n.html?emailaddress=miriam.bohn\%40t-online.de\#.

Rajasekhar, D., M. D. Babu, and R. Manjula. 2018. Decentralised Governance, Development Programmes and Elite Capture. Singapore: Springer Singapore.

Reifeld, Helmut. 2014. "Vom Machtpolitischen Instrument zum Demokratischen Wert: Dezentralisierung in Marokko." KAS Auslandsinformationen 30 (8): 93116.

Shaban, Abdur Rahman Alfa. 2018. "Egypt's First Coptic Christian Female Governor: Manal Awad Mikhael.” Africa News, August 30. Accessed March 11, 2021. https:/www.africanews.com/2018/08/31/egypt-s-first-coptic-christian-female-gov ernor-manal-awad-mikhael/. 
Shalaby, Marwa, Chagai Weiss, Ellen Lust, Kristen Kao, Erik Vollmann, Sylvia I. Bergh, Ezra Karmel, Miriam Bohn, Intissar Kherigi, and Zeynep Kadirbeyoglu. 2020. The Dynamics of Decentralization in the MENA: Processes, Outcomes, and Obstacles. GLD Working Paper No. 31. Gothenburg: GLD.

Sigman, Rachel, and Staffan Lindberg. 2017. Neopatrimonialism and Democracy: An Empirical Investigation of Africa's Political Regimes, V-Dem Working Paper Series 2017: 56. Gothenburg: V-Dem Institute.

Sturm, Roland, and Erik Vollmann. 2020. "Dezentralisierung - die Pragmatische Alternative zum Föderalismus in Autokratien? Der Fall Marokko.” In Jabrbuch des Föderalismus 2020, edited by EZFF, 179-194. Baden-Baden: Nomos.

Tadamun. 2015. "Comparing Two Forms of Local Administration: Can Decentralization in France be a Model for Egypt?” Tadamun, January 21. Accessed March 11, 2021. http://www.tadamun.co/comparing-two-similar-models-local-administ ration-can-decentralization-france-inspiration-egypt/?lang=en\#.Xy1H9DVCRhE.

Tafra. 2017. La Responsabilité des Élus dans le Cadre de la Régionalisation Avancée. Rabat: Tafra / TelQuel Media.

Teorell, Jan. 2007. "Corruption as an Institution: Rethinking the Nature and Origins of the Grabbing Hand.” QoG Working Paper Series 5. Gothenburg: QoG Institute.

Tarchouna, Lotfi. 2019. “The Tunisian Experience of Decentralization Since 2014.” Arab Reform Initiative, July 31. Accessed March 11, 2021. https://www.arab-refo $\mathrm{rm} . n e t /$ publication/the-tunisian-experience-of-decentralization-since-2014/.

Transparency International. 2020a. "Corruption Perceptions Index." Accessed March 11, 2021. https://www.transparency.org/en/cpi/.

Transparency International. 2020b. "Global Corruption Barometer." Accessed March 11, 2021. https://www.transparency.org/en/gcb.

Tritki, Khalid. 2015. “Elections Locales: La 'Chasse à l'Homme' a Commencé.” Medias24, July 22. Accessed March 11, 2021. https://www.medias24.com/NATION/ POLITIQUE/156754-Elections-locales-La-chasse-a-l-homme-a-commence.html.

UNDP and The Institute of National Planning, Egypt. 2004. Egypt Human Development Report 2004: Choosing Decentralization for Good Governance. Cairo: UNDP.

V-Dem Institute. 2020. “Global Standards, Local Knowledge.” Accessed March 11, 2021. https://www.v-dem.net/en/.

Venema, Bernhard, and A. Mguild. 2002. "The Vitality of Local Political Institutions in the Middle Atlas, Morocco." Ethnology 41 (2): 103-117. doi: 10.2307/4153001.

Vollmann, Erik. 2020. "Comparative Decentralization in the MENA." In The Dynamics of Decentralization in the MENA: Processes, Outcomes, and Obstacles, edited by Marwa Shalaby, Chagai Weiss, Ellen Lust, Kristen Kao, Erik Vollmann, Sylvia I. Bergh, Ezra Karmel, Miriam Bohn, Intissar Kherigi and Zeynep Kadirbeyoglu, 9-22. Gothenburg: GLD. 
Vollmann, Erik, Miriam Bohn, Roland Sturm, and Thomas Demmelhuber. 2020. "Decentralisation as authoritarian upgrading? Evidence from Jordan and Morocco.” The Journal of North African Studies, 1-32. doi: 10.1080/13629387.2020.17878 37.

Volpi, Frederic, Fabio Merone, and Chiara Loschi. 2016. "Local (R)evolutions in Tunisia, 2011-2014: Reconstructing Municipal Political Authority.” The Middle East Journal 70: 365-381. doi: 10.3751/70.3.11.

von Soest, Christian. 2010. What Neopatrimonialism Is - Six Questions to the Concept. Hamburg: German Institute for Global and Area Studies (GIGA).

Walter, Elsa. 2017. "Débat: qui est l'Élite Économique Marocaine?” Telquel, October 23. Accessed March 11, 2021. https://telquel.ma/2017/10/12/debat-qui-est-leli te-economique-marocaine_1563954.

White, Natasha. 2015. "Conflict Stalemate in Morocco and Western Sahara: Natural Resources, Legitimacy and Political Recognition.” British Journal of Middle Eastern Studies 42 (3): 339-357. doi: 10.1080/13530194.2014.949220.

Wolf, Anne. 2019. "In Search of 'Consensus': the Crisis of Party Politics in Tunisia." The Journal of North African Studies 24 (6): 883-886. doi: 10.1080/13629387.2019.1675249.

Yasun, Salih. 2020. Bureaucrat-Local Politician Linkages and Hierarchical Local Governance in Emerging Democracies: A Case Study of Tunisia, GLD Working Paper Series. Gothenburg: GLD.

Zaki, Lamia. 2019. "Decentralization in Morocco: Promising Legal Reforms with Uncertain Impact.” Accessed March 11, 2021. https://pdfs.semanticscholar.org/7 2a1/76eef30ccefcf0d806f58f2217ed9c3bb6c8.pdf.

Zerhouni, Saloua. 2004. "Morocco: Reconciling Continuity and Change." In Arab Elites: Negotiating the Politics of Change, edited by Volker Perthes, 61-86. Boulder, CO: Lynne Rienner. 
